\title{
On the macrofinancial determinants of life and non-life insurance premiums
}

\author{
Martin Hodula $^{1,2}$ (D) Jan Jankü ${ }^{1,2} \cdot$ Martin Časta $^{1,3} \cdot$ Adam Kučera $^{1}$
}

Received: 20 April 2021 / Accepted: 23 September 2021

(c) The Geneva Association 2021

\begin{abstract}
This paper tests potential determinants of the development of the insurance sector. Using a rich dataset for 24 European countries spanning two decades, we identify a set of macrofinancial factors that are the most robust predictors of growth of gross premiums in the life and non-life insurance sectors. We show that both life and nonlife premiums co-move with the business cycle and are positively related to higher savings and a more developed financial system. In addition, we provide new evidence on the role of market concentration and price effects. We find that market concentration matters only for life insurance, whereas the price channel is significant only for non-life insurance. From a policy perspective, our empirical estimates can be used to refine the existing macroprudential stress tests of the insurance sector.
\end{abstract}

Keywords Business cycle $\cdot$ Insurance $\cdot$ Life insurance $\cdot$ Macrofinancial determinants $\cdot$ Non-life insurance

\section{Introduction}

A healthy insurance sector is crucial for the functioning of the economy, as it contributes to economic growth and financial stability. By reducing the impact of large losses on firms and households and enabling risk to be pooled, the sector encourages

Martin Hodula

martinhodula@gmail.com

Jan Janků

jan.janku@cnb.cz

Martin Časta

martin.casta@cnb.cz

Adam Kučera

martin.casta@cnb.cz

1 Czech National Bank, Prague, Czech Republic

2 Technical University of Ostrava, Ostrava, Czech Republic

3 Prague University of Economics and Business, Prague, Czech Republic 
additional output, investment, innovation, and competition. Several empirical studies report evidence that increasing availability of insurance products promotes economic growth (Ward and Zurbruegg 2000; Haiss and Sümegi 2008; Lee et al. 2013; Peleckiené et al. 2019).

In turn, the stability of the insurance sector might significantly affect the stability of the financial system as a whole. After the Global Financial Crisis (GFC) of 2008-2009, policymakers began to wonder whether the insurance sector could become a source of systemic risk (Jobst et al. 2014). This growing uneasiness stems from the fact that the systemic risk contribution of the insurance sector has risen since the crisis. This concerns the common exposures within the sector as well as its interconnectedness with the rest of the economy (Acharya and Richardson 2014; Alves et al. 2015), in particular the banking sector (Nyholm 2012; Balcilar et al. 2018) but also the so-called shadow banking sector (Hodula et al. 2020).

Given the importance of the insurance sector, central banks and regulatory and supervisory authorities have attempted to incorporate the insurance sector into their prudential analytical toolkits, including their stress testing frameworks, in order to monitor the potential impact of adverse market and economic developments on the insurance sector with implications for systemic risk and financial stability (Jobst et al. 2014). However, studies providing policymakers with analysis of the main drivers of the insurance sector are scarce, at least when compared to the banking sector.

In this paper, we explore a broad set of factors that might drive the insurance sector. We compile a rich dataset of insurance premiums for 24 European countries over the 1997-2017 period. The dataset allows us to analyse separately the determinants of the life and non-life insurance businesses. Our empirical estimates can be utilised to refine the scenarios used in prudential macro stress tests of insurance companies. The determinants in life and non-life business are analysed separately because they differ significantly from each other, mostly in terms of the importance of various determinants and the nature of their cyclicity. ${ }^{1}$ Nonetheless, we still analyse both life and non-life insurance rather than focusing on only one of them, given that (i) the linkage between economic cycles and insurance is relevant for both life and non-life insurance and (ii) insurance companies or groups operate in the whole insurance market in many European countries. Therefore, while the econometric analysis is performed separately for life and non-life, the model specifications are similar and the results are commented on as a whole. We provide evidence on the linkages between the dynamics of the insurance sector, as measured by premiums written, and the path of real gross domestic product and other macrofinancial variables. Identification of such linkages can serve two purposes: (i) backward-looking evaluation of insurance sector growth rates and (ii) derivation of forward-looking

\footnotetext{
1 For example, contracts in non-life insurance are generally closed for a shorter period than in life insurance, which provides insurance companies with more flexibility to adjust the prices for non-life contracts along the business cycle, compared to life contracts. Also, demand for life insurance is more related to household wealth and its distribution (stock variables), whereas the demand for non-life insurance is linked mostly to economic performance (flow variables).
} 
insurance-specific scenarios from the macroeconomic scenarios used in prudential stress testing (IAIS 2013).

We show that the insurance sector co-moves with the business cycle. Moreover, and in contradiction to the previous line of work, we assert a significant role of the changing level of concentration in the sector, which affects insurance premiums. We also identify a non-trivial price channel in the case of the non-life insurance sector. Specifically, we demonstrate that changes in the price of a given insurance product are linked to a statistically significant increase in non-life insurance premiums, while we record no such relationship in the case of life insurance.

Furthermore, our estimates suggest that the price elasticity of demand can differ substantially between life and non-life insurance. Specifically, the demand for life insurance products seems to be highly price-inelastic, in contrast to the rather inelastic demand for non-life insurance. Such a finding is in line with the fact that part of life insurance products, namely those with investment elements, have close substitutes in the form of alternative investment product provided by banks or funds. In contrast, non-life insurance products often have no close substitutes.

We contribute to the literature on the determinants of the insurance sector in a number of ways. First, the majority of the existing empirical research focuses on explaining growth in the life insurance sector (Browne and Kim 1993; Outreville 1996; Beck and Webb 2003; Li et al. 2007; Alhassan and Biekpe 2016), whereas we explore the non-life sector as well. ${ }^{2}$ This enables us to draw a complete picture of the insurance sector. Second, we are among the first to accommodate European data, an area where conclusive evidence on insurance determinants was previously missing. Third, our ability to use micro-level data on individual insurance companies makes it possible to measure the effect of concentration in the insurance market on premiums. ${ }^{3}$ Fourth, given our focus on a European sample, we can match insurance premiums with changes in the price index of insurance products. By doing so, we are able to capture price effects that may significantly affect insurance premiums.

We identify three other studies that estimate the determinants of life and non-life insurance premiums (Feyen et al. 2011; Christophersen and Jakubik 2014; Gupta et al. 2019). Let us briefly explain how our analysis relates to theirs. First, we cover a substantially wider period, which allows us to track the factors that drive the insurance sector across multiple business cycles. Therefore, we can assess the sector's dynamics while incorporating both boom and bust periods. Second, we propose a novel solution to the issue raised in Beck and Webb (2003) regarding the effects of changes in insurance prices. Premium data by itself does not allow one to observe the actual amount of insurance coverage purchased, as such data is a combination of price and coverage. Thus, not considering price effects introduces substantial noise into the estimation (unless the price is constant across countries, which is unlikely).

\footnotetext{
${ }^{2}$ Earlier contributions include several country-specific studies (Hammond et al. 1967; Headen and Lee 1974; Burnett and Palmer 1984; Babbel 1985).

${ }^{3}$ Several studies use micro-level data to evaluate the effect of competition on efficiency (Fenn et al. 2008; Bikker and Van Leuvensteijn 2008) and solvency (Cummins et al. 2017) in the life insurance sector.
} 

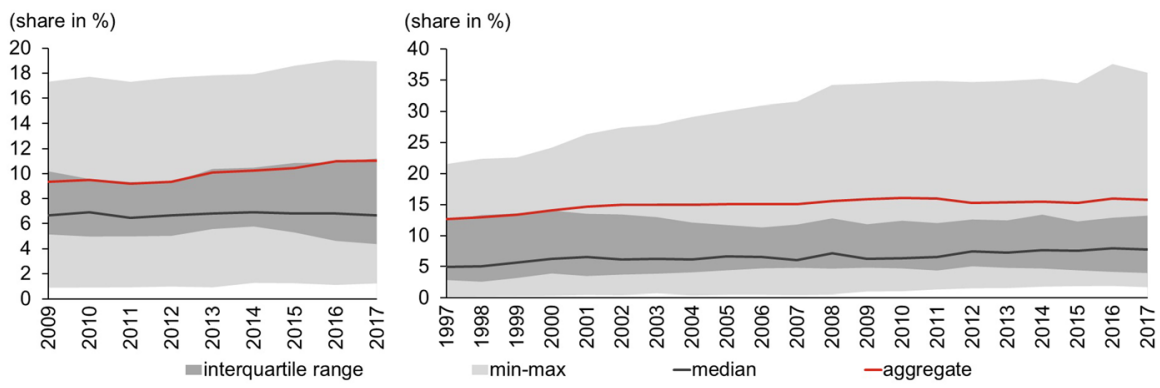

Fig. 1 Position of insurance companies in the European financial system. Note Left panel: insurance companies' assets over total financial system assets (since 2009). The values are calculated as the aggregate for the 24 European countries under analysis, with Switzerland missing in the case of the share of households' financial assets due to unavailable data. Some countries were excluded in certain years for which data was not available. Right panel: value of households' life insurance products as a share of their total financial assets. The shorter sample in 2009 in the case of the share in total assets is due to unavailable comparable data prior to 2009. Source OECD Insurance Statistics Database

The two aforementioned studies do not address this issue. Third, we deviate from the interpretation of some typical variables employed in models explaining developments in the insurance sector, such as life expectancy and the concentration ratio. Fourth, we use a cluster-robust estimator, which delivers more precise standard errors than those obtained using standard ordinary least squares (including fixed effects, FEs).

The remainder of the paper is organised into five sections. The next section provides stylised facts about the European insurance sector. The subsequent section introduces our data and methodology. Then, we section describe our baseline specification results. The penultimate section subjects our results to a battery of robustness tests. The final section concludes.

\section{Some stylised facts on the European insurance sector}

The insurance sector is an important component of the European financial sector, given the significance of its two main roles: (i) risk transfer by non-life insurance products and the risk components of life insurance products, and (ii) intermediation of the allocation of households' savings in the financial markets by the investment components of life insurance products. The latter role determines the amount of assets under management by insurance companies. The assets of the European insurance sector, composed mostly of financial investments, represented roughly $11 \%$ of the total aggregate assets of the European financial sector at the end of 2017. This share has grown slightly over the last decade, from 9.3\% in 2009 (Fig. 1, left panel). The share of life insurance in the allocation of households' savings in the financial markets rose from under 13\% of households' total financial assets in 1997 to more than $16 \%$ in 2010 and has remained roughly constant since then (Fig. 1, right panel).

The European insurance sector, however, is very heterogeneous. In most European countries, the share of the insurance sector in total financial assets (and that of life insurance products in households' balance sheets) is less than the aggregate 


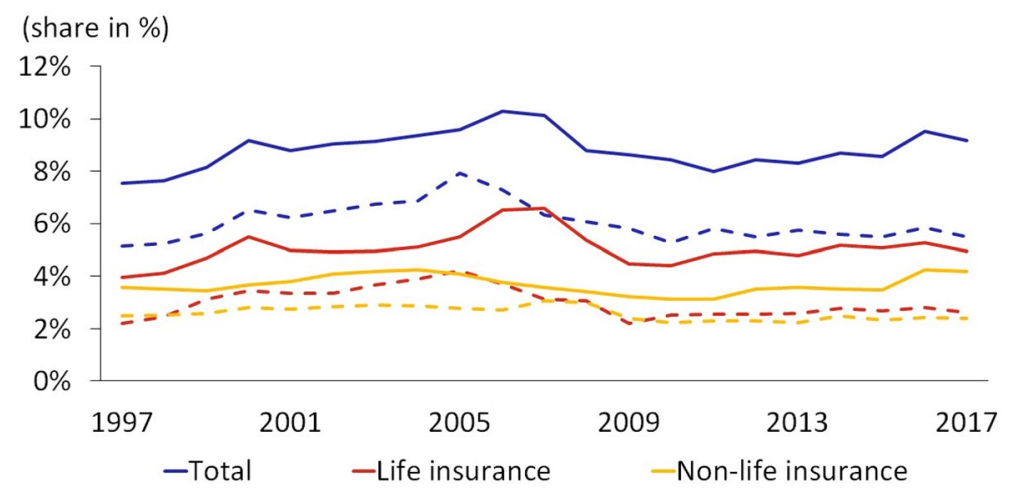

Fig. 2 Insurance penetration rate in European countries (gross premiums written/real GDP). Note dashed lines display medians, whereas solid lines display the aggregate values for the 24 European countries under analysis. Some countries were excluded in certain years due to data unavailability. Source AXCO Database and OECD National Accounts Database

value (see Fig. 1, aggregate values vs. other measures in both panels). The aggregate values are driven by a few countries with large financial sectors. Specifically, the U.K., France, and Germany together formed almost 50\% of the European financial sector at the end of 2017 by financial assets held. Insurance companies' assets represented more than $10 \%$ of the total assets of the financial sector in these countries (and as much as $18.4 \%$ in the case of France), while the share of life insurance products in household financial assets was $10.1 \%$ in the U.K., $16.8 \%$ in Germany, and as much as $36 \%$ in France. Conversely, both shares were less than 5\% for six countries (the Czech Republic, Estonia, Greece, Hungary, Latvia, and Lithuania).

The amount of investment intermediated by insurance companies primarily reflects the size of the life insurance segment. In contrast, non-life insurance may be seen as a regularly paid service rather than a tool for the accumulation of savings. Therefore, gross premiums written serve as a better indicator of the size of the segment. The penetration rate of insurance (the share of gross premiums written in GDP each year) shows the relative importance of the insurance sector in a country's overall economic output (Fig. 2). The penetration rate for life insurance was rising until the GFC. This phenomenon is partly explained by declining interest rates and growing stock markets in Western Europe during the pre-crisis period (Lorent 2008).

Since the crisis, the penetration rate has decreased slightly, mostly due to a longlasting low-yield environment, which has compressed returns on traditional insurance investment products and motivated households to seek different means of investing their savings (IAIS 2020). The penetration rate has remained roughly stable in non-life insurance, as the natural needs of economic agents to be protected against uncertainty and the affordability of non-life insurance are closely related to economic performance. Again, and simultaneously, there is sizable heterogeneity in the penetration rate across European countries, as signaled by the difference between the aggregate and median values, especially in the case of life insurance.

The non-decreasing penetration rate against a background of sustained economic growth implies that gross premiums written have been growing steadily over recent 


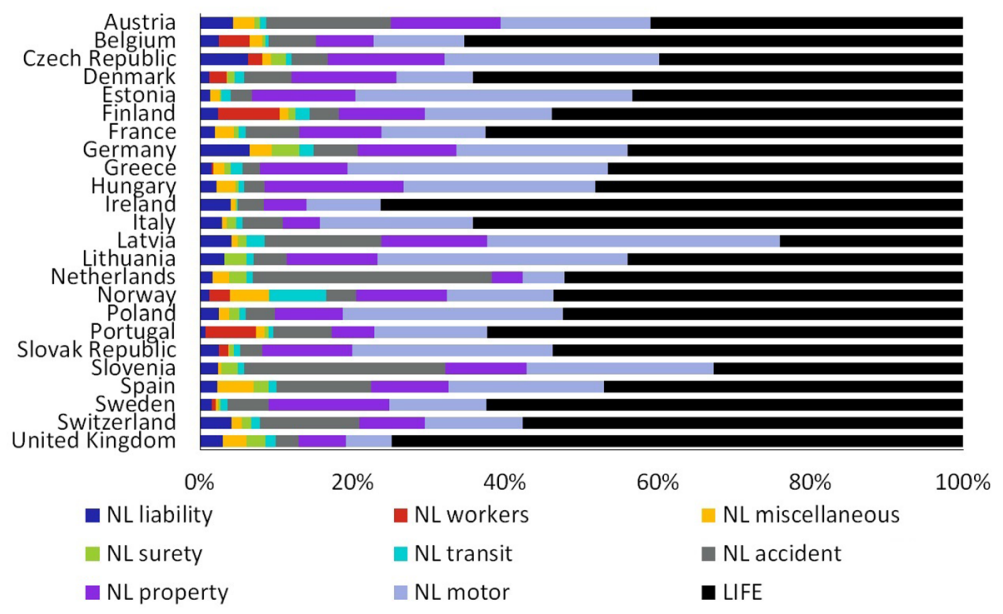

Fig. 3 Split of insurance sector, according to gross premiums written, into subsegments in European countries (average between 1997 and 2017). Note missing data in some years were either filled by linear interpolation or omitted (if missing at the beginning of the time period). NL non-life insurance. Source AXCO Database, CNB calculations

decades, except for the period of the GFC. This growth has been recorded for most of the insurance subsegments, while the volatility of the growth rate has varied significantly across both segments and countries. This is apparent from the width of the grey areas in Fig. 1. The differences between countries in growth rates, levels, and importance of the individual insurance subsegments (Fig. 3) are caused by various factors. These include the level of development of financial markets, the existence of public insurance schemes, the overall wealth and income situation of economic agents, and the natural need to be insured against specific risks. The heterogeneity in life insurance and its penetration is significantly affected by different shares of guaranteed and unitlinked products in life insurance across countries, which has also affected the growth of life insurance in the low-yield environment. Motor, property, and accident insurance account for over $60 \%$ of business in the non-life market in all European countries (and more than $80 \%$ in most cases). Significant differences among countries can be seen in the importance of accident insurance and also liability and workers' insurance. These empirical observations partly highlight the motivation of this paper. We aim to explain the dynamics of the insurance segments through the lens of gross premiums written, and especially their (dis)connection to overall economic growth, while controlling for differences among countries and insurance subsegments.

\section{Data, variables, and baseline empirical specifications}

We approach the empirical testing of the determinants of the insurance sector by means of multivariate regression analysis. This allows us to assess which of the determinants considered robustly explain the growth of the insurance sector. We estimate two sets of models-for life and non-life insurance-because the insurance sector offers a 
non-homogeneous set of products, which makes it impossible to model the insurance sector as a whole. Changes in the life and non-life insurance sectors are likely to be determined by different factors even though some determinants may be the same.

Our dependent variable is gross written insurance premiums expressed in growth rates for the life and non-life sectors collected for 24 European countries over more than three decades (1983-2017). However, data on some of the crucial explanatory variables is not available for all those countries since 1983. Our baseline sample therefore consists of a reduced 1997-2017 time span. The full time span (1983-2017) without some control variables serves as a robustness check. We work with an unbalanced panel.

Gross insurance premiums are calculated as the price times the quantity of insurance provided and, as such, can affected by both demand- and supply-side factors. Therefore, premiums are a joint outcome of both demand- and supply-side effects. Ideally, we would model the relationship between the supply of and demand for insurance separately. However, data limitations restrict empirical testing of such models. ${ }^{4}$ Moreover, since we cannot assume that prices of insurance products remain constant, we need to control for price effects. If they were omitted, we would run the risk of biased estimates, as price effects would introduce a substantial amount of noise into the regression.

We address the aforementioned issues in several ways that should jointly ensure unbiased estimates. First, we take advantage of the data harmonisation process that has taken place in the European Union, whose countries make up our sample. Among other things, the procedure ensures that inflation data are calculated according to harmonised definitions. This allows us to combine the information on insurance premiums with the harmonised index of consumer prices (HICP) category 'Insurance', which reflects changes in the pricing of insurance services. Second, while the HICP covers only households, we need to filter out the rest of the price effects from the demand firms) and supply side. To this end, we follow Beck and Webb (2003) and assume that the price is a function of several supply-side factors, such as the changing level of financial development, competition, and institutional development. Third, we use panel estimation with country-FEs, which should eliminate the rest of the potential bias.

\section{A model of insurance premiums}

Our model of life insurance premiums takes the following form:

$$
L I F E_{-} P R E M I U M S_{i t}=\beta G D P_{i t}+\gamma \mathbf{X}_{i t}^{\prime}+\mu_{i}+\epsilon_{i t},
$$

where the dependent variable LIFE_PREMIUMS $S_{i t}$ is the yearly change in gross written life premiums in percent. We also estimate a model of non-life insurance premiums:

\footnotetext{
${ }^{4}$ Distinguishing between demand- and supply-side effects is problematic even in bank lending studies (Jiménez et al. 2017).
} 

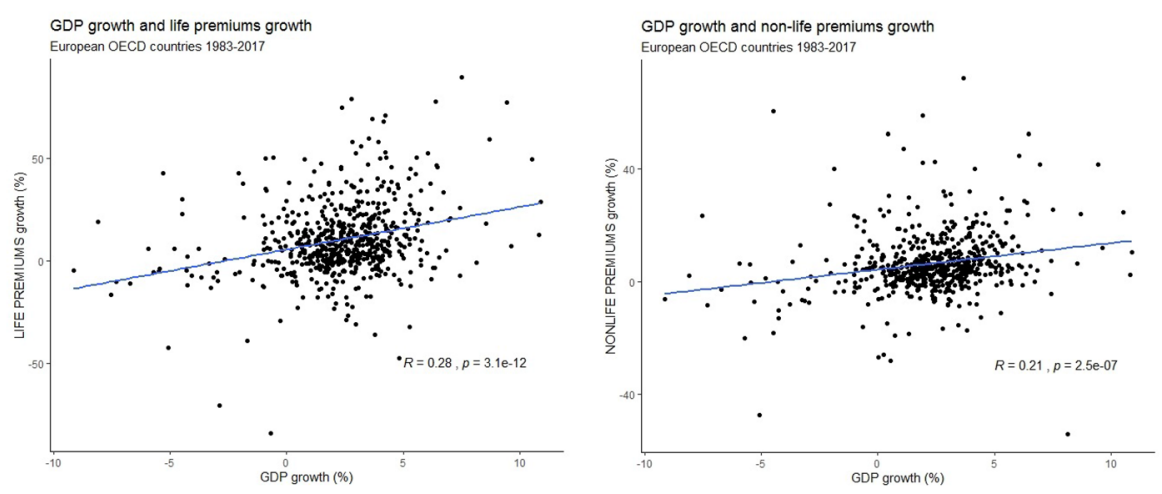

Fig. 4 Correlation between life and non-life premium growth and real GDP growth. Source AXCO Database and OECD Economic Outlook

$$
\text { NONLIFE_PREMIUMS } S_{i t}=\beta G D P_{i t}+\gamma \mathbf{Z}_{i t}^{\prime}+\mu_{i}+\epsilon_{i t},
$$

where the dependent variable NONLIFE_PREMIUMS ${ }_{i t}$ is the yearly change in gross written non-life premiums in percent. Indices $i$ and $t$ stand for countries and time periods (years). The variable $G D P_{i t}$ is the annual change in real gross domestic product (real GDP growth) and $\mathbf{X}_{i t}^{\prime}$ and $\mathbf{Z}_{\mathbf{i t}}{ }^{\prime}$ are row vectors of control variables. Finally, $\mu_{i}$ captures unobserved country-specific effects and $\epsilon_{i t}$ is an error term.

The variable $G D P_{i t}$ is a representation of the business cycle, and the related beta parameter can be considered a main parameter of interest. Given the wide range of information about the business conditions that is reflected in GDP, the resulting estimates allow us to identify the degree of connection between the business cycle and the dynamics of insurance premiums in specific segments..$^{5}$ The parameter values therefore implicitly shed some light on the position of the insurance sector from the systemic point of view as either an amplifier or an absorber of a possible adverse shock. Such information is crucial for the conduct of macroprudential stress tests, which evaluate the resilience of the financial sector in extreme situations such as an economic or financial crisis (IAIS 2013). A positive sign between insurance premiums and real GDP growth is expected, because an underperforming economy probably puts more strain on demand for insurance.

Figure 4 shows the simple correlations between life and non-life insurance premium growth and real GDP growth (both in percent). Although the scatter plots do not show a particularly strong relationship between those variables, the correlation coefficients are statistically significant and positive, as expected. A stronger correlation between real GDP growth and insurance premiums emerges for life insurance premiums.

\footnotetext{
5 The analysis would need to be widened in order to provide a complete evaluation of the cyclicality of the insurance sector and its implications for systemic risk. This would additionally need to involve an analysis of cyclicality in insurance claims, provisions, lapses, and the investment behaviour of insurance companies, most importantly. However, such analysis is beyond the scope of this paper.
} 


\section{Control variables}

Control variables were selected based on a review of the existing empirical studies (Table 6 in the Appendix). Some new, not previously considered, ones were added. For the life insurance premium model, the vector $X_{i t}^{\prime}$ comprises $\mathbf{X}_{i t}^{\prime}=\left[S O L V E N C Y I I_{i t}\right.$, SSCGOVREV $_{i t}$, INSHICP $_{i t}$, LIFEEXP $_{i t}$, ADR $_{i t}$, SAVINGS $_{i t}$, FDI $_{i t}$, LCONCENT $_{i t}$, CRISIS $\left._{i t}\right]$.

For the non-life premiums model, the vector is: $\mathbf{Z}_{i t}^{\prime}=\left[\operatorname{SOLVENCYII}_{i t}\right.$,

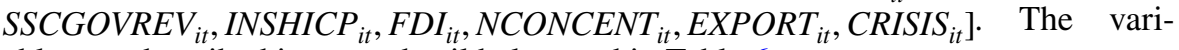
ables are described in more detail below and in Table 6.

The dummy variable $S O L V E N C Y I I_{i t}$ equals 1 since 2016 and 0 otherwise. It allows us to distinguish the period since the adoption of the Solvency II Directive. Motivation for including this variables lies in the fact that this directive significantly changed the insurance business in the EU. ${ }^{6}$ It introduced a risk-based capital regime with three pillars-(1) valuation of asset and liabilities in line with market conditions and calculation of capital requirement in a risk-based manner, (2) a supervisory review process and (3) reporting and transparency requirements. Therefore, the directive might cause significant changes in the risk management of insurance companies as well as their capital planning, and thus also in pricing of certain insurance products and/or their profitability. Also, the transition to Solvency II led to a reclassification of certain lines of business, so failing to account for it would result in false attribution of the premium volatility after 2016. Especially in the case of health insurance, Solvency II brought in a substantial change by dividing it into life and non-life segments according to its similarity to one segment or the other. Given these arguments, we consider attributing for the adoption, using the dummy variable as necessary. Unlike our period of analysis, previous studies date from the period prior to the adoption of the Solvency II Directive and thus do not include such a dummy in their models.

The variable $S S C G O V R E V_{i t}$ represents the ratio of social security contributions to overall government revenues. We expect a negative sign because a more generous social security system probably lowers the necessity for additional private insurance (a substitute sui generis). From this point of view, social security protection (on average) acts as substitute for, rather than a complement of, life insurance. As Table 6 shows, most studies assume that social security schemes provide protection against mortality risk and should therefore affect life insurance demand negatively. Some studies, however, argue that the effect could be ambiguous (Browne and Kim 1993; Feyen et al. 2011).

The variable INSHICP $P_{i t}$ is the change in the harmonised consumer price index of insurance products. This variable represents the price part of the growth in insurance premiums. The variable fully captures price growth in the non-life sector from the perspective of households. The life sector is not covered, so the variable serves more as an approximation of price growth in life insurance. ${ }^{7}$ Rising prices of insurance

\footnotetext{
6 See, for example, https://ec.europa.eu/commission/presscorner/detail/en/MEMO_15_3120 for reference.

7 More specifically, according to the Classification of Individual Consumption by Purpose (COICOP), it is category CP125-Insurance. This does not cover life insurance, but includes health, education, and social protection services, as well as insurance and financial services.
} 
products should naturally increase the volume of insurance premiums (a positive expected sign). The reviewed studies usually employed a general inflation variable, since they relied on large international panels, which prohibited them from categorising inflation in insurance services. General inflation, however, cannot be used to capture price effects but serves rather as a proxy for monetary uncertainty (Beck and Webb 2003). Given our focus on European countries, we can benefit from the harmonisation procedure for measuring inflation across different product and service categories and match insurance premiums with changes in the price index of insurance products.

Life expectancy $L I F E E X P_{i t}$ and the age dependency ratio $A D R_{i t}$ together control for demographic trends. Higher life expectancy implies a more sophisticated healthcare system and could therefore reduce the demand for private security. At the same time, life expectancy captures the economic level of the country, and it can be assumed that insurance growth will be lower in more developed countries, as current insurance saturation is higher (a negative expected sign). However, an ageing population, captured by $A D R_{i t}$, featuring a growing number of retirees may imply decreased demand for insurance because of the lower purchasing power of retired persons. Previous studies have reported strongly mixed estimates, ranging from very negative (Feyen et al. 2011) to positive (Outreville 1996) or not significant (Beck and Webb 2003). We incorporate the two variables mainly to find out what is driving the mixed estimates and to explain them. The main problem seems to be that the above-mentioned studies do not consider the fact that higher life expectancy may covertly reflect a country's level of development.

The variable $S A V I N G S_{i t}$ is the savings rate and reflects the part of disposable income that, together with the incurrence of liabilities, is available to acquire financial and non-financial assets. We suppose that a higher savings rate enhances the growth of insurance premiums. This is because investment in life insurance can also reflect a savings motive. Previous studies do not include any variable for savings in the regressions (Table 6), but, for example, Headen and Lee (1974) show that the demand for life insurance depends on net saving. They argue that the short-run behaviour of life insurance demand is affected by household portfolio decisions. Given a portfolio of financial assets, the flows into specific assets are a function of decisions to save as well as decisions as to portfolio composition. They expect higher rates of net saving to be positively associated with life insurance demand, since life insurance is hypothesied as a primary financial asset alternative for lowasset holders.

The financial development index $F D I_{i t}$ is taken from Svirydzenka (2016) and is meant to capture the level of financial development. We use year-to-year changes of FDI as our explanatory variable. While banks are typically the largest and most important part of the financial sector, in more developed systems mutual funds and pension funds also play substantial roles. The combination of such financial institutions and markets facilitates a higher rate of provision of financial services and probably a higher volume of insurance premiums. Previous studies generally rely on a single indicator to capture the level of financial development. Outreville (1996) was the first to document a positive relationship between life insurance consumption and the complexity of the financial structure, defined as the ratio of quasi-money 
(M2-M1) to the broad definition of money (M2). This empirical strategy was also adopted by Li et al. (2007). Beck and Webb (2003) and Feyen et al. (2011) approximate the level of financial development by the ratio of private credit/total banking assets to GDP. This approach, however, might be insufficient, as the diversity of financial systems across countries implies a need to look at multiple indicators to measure financial development (Sahay et al. 2015). Using a composite indicator such as $F D I_{i t}$ thus allows us to incorporate information from multiple segments of the financial system.

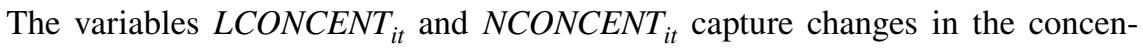
tration ratios of the life and non-life insurance sectors. The concentration ratio is calculated using micro-level data on individual insurance companies. Specifically, we collected information on insurance premiums for 15,083 life insurance companies and 18,291 non-life insurance companies and calculated the market share of the four largest insurance companies. ${ }^{8}$ Details on the concentration ratio are provided in Fig. 6 in the Appendix. Higher market concentration should, according to the theory of imperfect competition, lead to somewhat restricted market supply, and the effect on the quantity of insurance premiums should be negative (quantity channel). However, higher market concentration also enhances the price channel of insurance premium growth (positive effect). We are therefore unsure a priori about the overall effect. The way we calculate the concentration ratio differs substantially from the rest of the empirical studies. Outreville (1996) and Feyen et al. (2011) create a binary dummy variable indicating whether the market is more or less concentrated. In this respect, Outreville (1996) notes that a concentration ratio would be a more appropriate measure than a simple dummy. ${ }^{9}$

The variable $E X P O R T_{i t}$ is a proxy for the country's involvement in cross-border trade. It is calculated as the annual growth rate of exports. We expect countries that are more involved in world trade to show higher growth in insurance premiums. This is mainly because some of the risks associated with international trade can be insured against. On the other hand, greater involvement in world trade may mean more foreign competition in the insurance sector (in the form of branches or subsidiaries of foreign insurance companies), which could ultimately lead to a fall in insurance product prices. Thus, we are unsure a priori which of the effects prevail. Trade openness is not regularly included in the previous studies on the determinants of insurance premiums. The one exception is Feyen et al. (2011), who find that the non-life sector seems to be positively and significantly affected by the volume of external trade.

\footnotetext{
${ }^{8}$ We also experimented with different cut-offs. Using the three or five largest companies yielded quantitatively similar estimates.

9 Outreville (1996) only investigates the life insurance sector and controls for market concentration using a simple 0/1 dummy for the absence/presence of monopoly power in the insurance market in the particular country. This procedure seems inadequate, as it does not sufficiently capture the rate of concentration and its variability, which is not constant over time at all. Outreville (1996) himself adds that the appropriate variable to test in this context, if available, would be a measure of the concentration ratio. Similarly, Feyen et al. (2011) construct a dummy variable which assigns 1 to more concentrated markets, for example, markets where the largest market player covers more than $50 \%$ of the assets of the market.
} 
The dummy variable $C R I S I S_{i t}$ equals 1 in 2008-2009 and 0 otherwise. It represents the exceptional period of the GFC, when insurance premiums fell sharply due to a negative demand shock. It is meant to capture any time-related effects that are not already in the model but may be related to this special event, which occurred during the timespan of our data. Theoretically, the crisis could have substantially affected demand for life and non-life insurance, reducing an individual's ability to buy insurance products due to unemployment, uncertainty, or lack of funds. No crisis-related dummy has been included in previous studies.

In addition to the variables mentioned above, we tested a number of variables suggested by the relevant literature (Table 6). Some of them could not be included due to collinearity with other variables. This concerns, for instance, the pairing of real GDP growth with the rate of unemployment and private credit growth with the financial development index. Some of the variables showed inconsistent results in our regressions (interest rates and income inequality), and others have very low variability in our sample (education and religion). As we examine the effect of real GDP growth on insurance premiums, we deliberately did not include variables as a share of GDP in the regressions. In such a case, there would be a risk of significant collinearity among these variables, and the coefficient on real GDP growth could be significantly affected. This applies in particular to EXPORT $T_{i t}$ and $S S C G O V R E V_{i t}$, which are often reported as a share of GDP.

Finally, we admit that there is a range of additional factors that affect the insurance premiums but are not included in our empirical model. These predominantly include factors at the micro-level related to both the behaviour of (prospective) policyholders and insurance companies that may not be fully captured by the control variables used. Such factors include, among others, changes in marketing expenses for insurance products, changes in distribution channels (joint provision of banking, insurance and investing financial products in the first place), shifts in consumption trends or risk aversion beyond the economic cycle, or the underwriting cycle in nonlife insurance. The reason for omitting these factors is an absence of data that would allow us to measure these factors. Still we believe that the selected set of control variables is sufficient to limit a possible omitted variable bias to a reasonable level, being also encouraged by a similar selection of the set of control variables in related studies (Table 6).

\section{Estimation method}

Building on the previous literature, we employ panel data and an OLS estimator with one-way FEs. In the panel data sample, we have to control for unobserved countryspecific effects $\mu_{i}$ (see Eqs. 1 and 2). Without controlling for them, the simple OLS estimator would be biased. Most empirical studies therefore employ the fixed-effects estimator in order to allow for cross-country differences. The country-specific effects control for further country-specific heterogeneity such as the geographical location of the country, its cultural and historical heritage, and norms and regional conventions related to insurance policy. They also capture religious differences (although 
Table 1 Descriptive statistics of the sample (1997-2017)

\begin{tabular}{lcrrrrrrr}
\hline & $\mathrm{n}$ & \multicolumn{1}{c}{ Mean } & \multicolumn{1}{c}{ SD } & Median & \multicolumn{1}{c}{ Min } & \multicolumn{1}{c}{ Max } & Skew & Kurtosis \\
\hline LIFEPREMIUMS & 399 & 6.91 & 18.05 & 4.38 & -70.17 & 157.82 & 1.86 & 13.46 \\
NONLIFEPREMIUMS & 401 & 4.79 & 11.33 & 3.92 & -54.20 & 71.95 & 1.03 & 9.21 \\
SOLVENCYII & 499 & 0.09 & 0.29 & 0.00 & 0.00 & 1.00 & 2.81 & 5.91 \\
GDP_GROWTH & 482 & 2.28 & 3.36 & 2.32 & -14.81 & 25.16 & -0.27 & 8.18 \\
SSCGOVREV & 482 & 30.30 & 9.60 & 32.07 & 0.11 & 45.01 & -1.22 & 1.81 \\
INSHICP & 433 & 3.29 & 5.51 & 2.60 & -25.30 & 42.00 & 1.98 & 12.68 \\
LIFEEXP & 492 & 78.13 & 3.39 & 78.90 & 69.10 & 83.70 & -0.65 & -0.49 \\
SAVINGS & 462 & 4.24 & 6.28 & 4.67 & -17.00 & 25.43 & -0.64 & 1.59 \\
ADR & 498 & 49.67 & 4.27 & 49.80 & 38.60 & 68.70 & 0.01 & 1.02 \\
FDI & 475 & 0.00 & 0.03 & 0.00 & -0.16 & 0.19 & -0.22 & 4.87 \\
LCONCENT & 406 & 0.06 & 3.55 & -0.18 & -13.68 & 17.25 & 0.68 & 2.93 \\
NCONCENT & 396 & 0.21 & 3.70 & -0.28 & -14.26 & 21.47 & 1.37 & 7.01 \\
EXPORT & 468 & 7.49 & 9.07 & 7.35 & -23.44 & 51.32 & 0.02 & 2.57 \\
CRISIS & 499 & 0.10 & 0.30 & 0.00 & 0.00 & 1.00 & 2.73 & 5.47 \\
\hline
\end{tabular}

these are less significant across European countries) and the different attitudes of nations to risk.

For all the results, we use a cluster-robust estimator (cluster-robust standard errors at the country level) to allow for within-country correlation of the residuals. This is because in models based on OLS (including FE), statistical inference using clustered standard errors is incorrect (despite the estimates being unbiased).

We also monitor stationarity of the variables in our estimations. An econometric theory for panel data was developed for studies where $\mathrm{T}$ is small but $\mathrm{N}$ is large. The asymptotic statistical theory was derived by letting $\mathrm{N} \longrightarrow \infty$ for a fixed $\mathrm{T}$; this is in contrast to today's time-series analyses, which often operate with a large T. Since time-series data tends to be non-stationary, determining the order of integration of the variables becomes important (see Smith 2000 for more details).

\section{Data}

The choice of independent variables is based on their theoretical relationship with insurance premium growth. For the purposes of this study, 12 country- and timespecific variables were considered as explanatory variables in our models. Table 1 shows basic descriptive statistics.

Data on insurance premiums was scraped from the AXCO Global Statistics Database. Data on concentration ratios was calculated from microdata on individual insurance companies from AXCO Company Statistics. The variables $G D P_{i t}$, $S S C G O V R E V_{i t}, L I F E E F E X P_{i t}$, and $A D R_{i t}$ were obtained from OECD Economic Outlook No 106 (November 2019). The data on $I N S H I C P_{i t}$ is from the ECB statistical database. The data on $F D I_{i t}$ is from the IMF's Financial Development Index Database. The variables SAVINGS ${ }_{i t}$ and EXPORT $T_{i t}$ are from the World Bank 
statistical database. ${ }^{10} \mathrm{We}$ omit extreme outliers, i.e. those of more than three times the interquartile range, from the data on life and non-life insurance premium growth. They account for less than $1 \%$ of the observations. Let us also add that the number of observations is lower in the regressions where concentration ratios are included. This is because of a lack of microdata on the concentration ratios of the life and nonlife insurance sector (generally available at the earliest since 1997 for some countries). Therefore, as a robustness check, we also employ some regressions without those variables later in the paper.

\section{Empirical results}

This section describes the results of the regression analysis of life and non-life insurance premiums. Table 2 presents our benchmark regressions. The first two columns (1) and (2) show the results for the life premium regressions and the last two columns (3) and (4) present those for the non-life premium regressions. Moreover, columns (1) and (3) exclude the variable LIFEEXP because we find it to be problematic, although many previous studies include it (for more details, see The role of demographic factors section).

We report point estimates together with cluster-robust standard errors in parenthesis. For clarity, we group the discussion of our estimates into five subsections. Since we strive to deliver robust estimates of determinants in the insurance sector, we contrast our results with those of earlier studies if possible and highlight where and why we deviate from them.

\section{Sensitivity of insurance premiums to the business cycle}

We confirm that life insurance premiums are inherently related to the business cycle. GDP_GROWTH enters significantly with its expected positive sign at the $1 \%$ level. Our point estimate for this variable is found to be somewhat sensitive to the inclusion of the life expectancy variable, which is discussed in the role of demographic factors section. Excluding life expectancy, the point estimate comes in at 1.06 , indicating that a one standard deviation increase in real GDP growth would be associated with a $3.55 \%$ increase in life insurance premiums. ${ }^{11}$ Since the estimated coefficients are linear in nature, we can state that the life insurance sector is found to be more prone to business cycle turnarounds. This supports the non-trivial conclusion that life insurance can be considered a luxury good.

\footnotetext{
10 We also considered using Solvency II data, which would be a valuable source of possible additional details on insurance undertakings or country-level control variables. However, the Solvency II data is limited to the last five years, covering only part of a business cycle (the growth phase and the initial months of the crisis in 2020). Therefore, given the focus in our analysis on understanding the longer-term determinants and the relationships between business cycles, financial cycles, and insurance premium growth, we consider the short period covered by the Solvency II data to be insufficient and leave such analysis for future research.

11 The one standard deviation impact is calculated as the point estimate over one standard deviation.
} 
Table 2 Determinants of life and non-life premiums, 1997-2017

\begin{tabular}{|c|c|c|c|c|}
\hline & \multicolumn{4}{|l|}{ Dependent variable } \\
\hline & \multicolumn{2}{|l|}{ LIFEPREMIUMS } & \multicolumn{2}{|c|}{ NONLIFEPREMIUMS } \\
\hline & (1) & (2) & (3) & (4) \\
\hline GDP_GROWTH & $\begin{array}{l}1.056 * * * \\
(0.251)\end{array}$ & $\begin{array}{l}0.856 * * * \\
(0.259)\end{array}$ & $\begin{array}{l}0.546^{* *} \\
(0.255)\end{array}$ & $\begin{array}{l}0.448 * \\
(0.238)\end{array}$ \\
\hline SOLVENCYII & $\begin{array}{l}-8.824 * * * \\
(3.135)\end{array}$ & $\begin{array}{l}-5.711^{* *} \\
(2.814)\end{array}$ & $\begin{array}{l}2.163 \\
(1.777)\end{array}$ & $\begin{array}{l}4.582 * * \\
(2.053)\end{array}$ \\
\hline SSCGOVREV & $\begin{array}{l}-1.770 * * * \\
(0.568)\end{array}$ & $\begin{array}{l}-1.482 * * \\
(0.624)\end{array}$ & $\begin{array}{l}-0.257 \\
(0.527)\end{array}$ & $\begin{array}{l}-0.141 \\
(0.473)\end{array}$ \\
\hline INSHICP & $\begin{array}{l}-0.090 \\
(0.185)\end{array}$ & $\begin{array}{l}-0.289 * * \\
(0.136)\end{array}$ & $\begin{array}{l}0.674 * * * \\
(0.084)\end{array}$ & $\begin{array}{l}0.586 * * * \\
(0.076)\end{array}$ \\
\hline SAVINGS & $\begin{array}{l}0.967 * * * \\
(0.285)\end{array}$ & $\begin{array}{l}0.807 * * \\
(0.315)\end{array}$ & & \\
\hline FDI & $\begin{array}{l}1.386 * * * \\
(0.446)\end{array}$ & $\begin{array}{l}1.250 * * * \\
(0.451)\end{array}$ & $\begin{array}{l}-0.385 \\
(0.298)\end{array}$ & $\begin{array}{l}-0.460 \\
(0.331)\end{array}$ \\
\hline LCONCENT & $\begin{array}{l}0.873 * * * \\
(0.303)\end{array}$ & $\begin{array}{l}0.915^{* * * *} \\
(0.292)\end{array}$ & & \\
\hline LIFEEXP & & $\begin{array}{l}-3.370 * * * \\
(0.872)\end{array}$ & & $\begin{array}{l}-1.412^{* * *} \\
(0.460)\end{array}$ \\
\hline ADR & $\begin{array}{l}-0.001 \\
(0.671)\end{array}$ & $\begin{array}{l}0.743 \\
(0.652)\end{array}$ & & \\
\hline NCONCENT & & & $\begin{array}{l}-0.009 \\
(0.181)\end{array}$ & $\begin{array}{l}0.019 \\
(0.191)\end{array}$ \\
\hline EXPORT & & & $\begin{array}{l}-0.112^{* *} \\
(0.052)\end{array}$ & $\begin{array}{l}-0.116^{* *} \\
(0.053)\end{array}$ \\
\hline CRISIS & $\begin{array}{l}-8.076^{* *} \\
(3.423)\end{array}$ & $\begin{array}{l}-6.262 * \\
(3.189)\end{array}$ & $\begin{array}{l}-3.905^{* *} \\
(1.708)\end{array}$ & $\begin{array}{l}-3.704^{* *} \\
(1.618)\end{array}$ \\
\hline Observations & 354 & 354 & 343 & 343 \\
\hline $\mathrm{N}$ (countries) & 24 & 24 & 24 & 24 \\
\hline $\mathrm{R}^{2}$ & 0.194 & 0.225 & 0.141 & 0.156 \\
\hline Adjusted $\mathrm{R}^{2}$ & 0.113 & 0.145 & 0.056 & 0.069 \\
\hline F Statistic & $8.573 * * *(\mathrm{df}=9 ; 321)$ & $\begin{array}{l}9.272 * * *(\mathrm{df} \\
\quad=10 ; 320)\end{array}$ & $\begin{array}{l}6.398 * * *(\mathrm{df} \\
=8 ; 311)\end{array}$ & $6.389 * * *(\mathrm{df}=9 ; 310)$ \\
\hline
\end{tabular}

Cluster-robust standard errors are in parentheses

Statistical significance at the $1 \%, 5 \%$, and $10 \%$ level is indicated by $* * *, * *$, and *, respectively

In addition, we find that non-life insurance premiums are also positively related to the business cycle. The point estimate of 0.55 is somewhat lower than the life insurance estimate, but its significance at the 5\% level allows for the effect to be as large as 1.05. A one standard deviation increase in real GDP growth would then translate into a $3.53 \%$ increase in non-life insurance premiums. 
The positive relationship between insurance premiums and real GDP growth may be further supported by possible shifts in portfolio allocation following adverse financial market developments and possible life insurance policy lapses, for instance. The insurance sector may, on the other hand, still maintain certain counter-cyclical features that are not reflected by the premium dynamics. These include claims paid to banks from credit insurance policies and claims paid to non-financial corporations under various business insurance policies. Therefore, our results show only one aspect of cyclicality and cannot be considered proof of procyclicality of the insurance sector as a whole.

The estimated parameter values can be directly and easily used in macroprudential stress testing by deriving the insurance income dynamics from business cycle scenarios. More specifically, to build a baseline macrofinancial scenario, the estimated sensitivity of insurance premiums to GDP_GROWTH provides a direct extension of the business cycle scenario to the insurance premium scenario. In the case of the scenario assuming a systemic financial crisis, the $D U M M Y$ variable parameter can additionally be used to obtain a scenario for adverse developments similar to the case of the GFC.

\section{Price effects across life and non-life insurance}

We record stark differences in the estimates regarding price effects between the life and non-life insurance sectors. We find changes in INSHICP to be associated with a statistically significant increase in non-life insurance premiums, while we record no such relationship in the case of life insurance. In this respect, we largely deviate from the point estimates of other studies, as we are the first to accommodate changes in insurance prices in our regression, while the previous studies either omit price effects or use a general inflation variable.

As Feyen et al. (2011) state, inflation is expected to have a negative effect on the demand for life insurance, as it erodes the value of insurance policies and makes them less attractive. This intuition is confirmed by several other studies (Table 6). Nevertheless, Feyen et al. (2011) ultimately identified a positive sign of the general inflation variable in all their non-life regressions and found this to be surprising.

We believe that the surprisingly positive sign reported in Feyen et al. (2011) can be at least partly explained by the fact that the general inflation variable largely captures prices of real goods such as cars and real estate. Growth in the prices of such goods naturally raises the prices of non-life insurance premiums. As non-life insurance premiums reflect both quantity and price growth (that is, growth in the volume of premiums, not just the number of contracts), rising prices of real estate lead to rising prices of non-life insurance. Our more precise INSHICP variable supports this explanation, as it covers price growth in the non-life insurance sector much better than general inflation.

For the life insurance sector, the variable INSHICP shows not significant or negative impact on premiums. The statistically not significant estimate is not surprising, since our price variable captures developments in the non-life sector only, while for the life sector it serves rather as an approximation. Building on this and 
taking the INSHICP as a proxy for wider price movements, the negative sign can be partly explained also by the above-mentioned intuition of Feyen et al. (2011), who expected inflation to have a negative effect on the demand for life insurance, as it erodes the value of insurance policies and makes them less attractive. An additional economic explanation using demand/supply elasticity can also be considered, as the sign and the significance of the $I N S H I C P_{i t}$ parameter could reflect the elasticity of the demand/supply curve. INSHICP ${ }_{i t}$ close to zero or even negative in life insurance means that a growth (a decrease) in life insurance prices triggers the same or a larger decrease (increase) in the volume of policies so that the volume of premiums moves oppositely to the change in price. This signals a highly elastic demand in life insurance that rapidly responds to changes in prices in life insurance. Such interpretation is in line with the fact that life insurance products, namely their investment components, have close substitutes in the form of investment products provided by banks or funds. This is in a contrast with non-life insurance, where the volume of premiums increases together with increasing prices, although less then proportionallythe demand for non-life insurance products decrease only partially after an increase in price, which is in line with the fact that non-life insurance products have no close substitutes.

\section{The role of market concentration}

The implications of changes in the concentration of the insurance market have not been sufficiently studied yet. Given our ability to calculate the concentration ratio using microdata on individual insurance companies, we provide robust evidence on the effects of market concentration and complement the findings of Outreville (1996) and Feyen et al. (2011).

We discover that changes in the level of concentration significantly affect life insurance premiums. The average point estimate across specifications (1) and (2) of 0.89 indicates that a one standard deviation increase in LCONCENT is associated with about a $3.02 \%$ increase in premiums. The result contradicts that of Outreville (1996), who reports a negative and significant effect. The negative and significant effect could normally be explained by the theory of imperfect competition that a more concentrated sector restricts market supply. However, as he adds, a lot of countries are characterised by the existence of a large number of small companies with small insurance capacity. Countries with a high concentration of insurance business in few companies, however, have been more successful in developing insurance services (that is, higher insurance premium growth should be expected with a higher concentration ratio). Thus, the positive sign on LCONCENT is theoretically sound. We add that higher market concentration probably enhances the price channel of insurance premium growth, which puts additional upward pressure on insurance premiums, measured as volumes and not just the number of contracts. This explanation is, of course, very closely linked to our debate on the possibilities of the variable INSHICP. If this variable does not fully capture price growth in the life insurance sector, its role can be partially taken over by the LCONCENT variable. 
The reported insignificant coefficient on the concentration ratio in the non-life sector (NCONCENT) contrasts with the concentration ratio estimate for the life sector $(L C O N C E N T){ }^{12}$ A superficial explanation would be that the price channel of the concentration variable is largely captured by INSHICP, so NCONCENT has no positive and significant effect. However, we would also have to ask why there is no significant and negative effect of the concentration ratio due to the quantity channel (a limited quantity offered according to the theory of imperfect competition).

We should therefore also consider whether: (i) the whole non-life sector differs substantially from the life sector, so while higher concentration has no effect in the former, it has a significant effect in the latter (and needs closer examination); (ii) the non-life sector is too heterogeneous, so while higher concentration promotes insurance in a particular subsector, it suppresses growth in other subsectors; (iii) our sample is too heterogeneous, so while non-life insurance in more developed countries may benefit from greater concentration of the sector, the non-life insurance volume in less developed countries may decrease due to concentration. We test both sector and sample heterogeneity as part of our robustness check in the Robustness check section.

\section{The role of demographic factors}

Following the previous line of work on the topic, we include the life expectancy variable in the second regression specification (Table 2, second column). LIFEEXP has a coefficient point estimate of -3.37 at the $1 \%$ level of significance. This implies that a country which advances its expected life length by one year would record a decrease in life insurance of $3.37 \%$. This is close to the average point estimate of -3.4 recorded by Feyen et al. (2011).

However, we have a serious objection to the inclusion of life expectancy in the model of life insurance premiums. Feyen et al. (2011) argue that most researchers expect life expectancy to have a negative impact on the demand for life insurance, on the grounds that longer life expectancy is associated with a lower probability of premature death and a lower need for life insurance. The rest of the studies, however, provide very mixed results on this issue. In fact, the relationship might equally be positive, as a longer life could stimulate higher demand for life insurance (pensions). ${ }^{13}$

We test the hypothesis of Feyen et al. (2011) and include the variable also in the regression for non-life premiums (Table 2, fourth column). Surprisingly, we find that it, too, produces a significant and negative coefficient of -1.4 at the $5 \%$ level. However, the hypothesis that life expectancy has a negative impact on insurance premium growth (through a lower probability of premature death) cannot be applied to

\footnotetext{
12 We add that this result is consistent with the findings of Feyen et al. (2011), who also report insignificant results for non-life premiums in contrast to a positive effect for life premiums.

13 Estimates of the importance of life expectancy as a determinant of life insurance premiums vary from positive (Outreville 1996) to negative ( $\mathrm{Li}$ et al. 2007), while most authors report insignificant results (Browne and Kim 1993; Beck and Webb 2003).
} 
non-life insurance. In fact, the opposite could be expected, because one can argue in a similar way that a lower probability of premature death should incentivise economic agents to insure their property because they will enjoy it for longer. Moreover, we find the life expectancy indicator to be strongly correlated with GDP per capita. Consequently, countries with higher GDP per capita (developed countries) naturally record lower insurance premium growth rates because of a previous higher level of insurance premium saturation.

Overall, we find evidence that life expectancy captures convergence effects rather than improvements in the healthcare system or in the general health of the population. While it produces highly significant estimates, it needs to be interpreted with caution.

\section{Financial development, social security and savings}

We find higher savings and a more developed financial system to increase the growth of life insurance premiums. Specifically, increasing FDI by one unit increases the growth rate of life insurance premiums by approximately 1.3 percentage points (pp) at the $1 \%$ level of significance [the average point estimate across specifications (1) and (2) in Table 2]. Similarly, increasing SAVINGS by 1 pp generates an increase in premiums of around $0.85 \mathrm{pp}$. These estimates are not surprising given that insurance can be generally regarded as another form of saving. As Yaari (1965) points out, the demand for life insurance is properly considered within the context of the consumer's lifetime allocation process. Each utility-maximising household has the same degree of relative risk aversion, and during its lifetime any excess gross savings can be converted into any of the financial products offered by insurance companies.

Social security contributions (SSCGOVREV) enter significantly with an average impact of $-1.63 \mathrm{pp}$. Social security payments seem to displace private insurance. The more generous these benefits are, the lower the demand for private assurance is likely to be. Our results therefore support the hypothesis that social security schemes at least partially substitute for private life insurance. Social security schemes provide protection against mortality risk and should therefore affect life insurance demand negatively. Our estimates are in line with those of Browne and Kim (1993). ${ }^{14}$

The CRISIS dummy shows that the non-life sector was hit especially hard by the GFC. The results for the life sector are also accompanied by a negative sign, but the estimates are not statistically significant. Table 9 in the Appendix shows the same empirical setting, but without the crisis dummy. The results are consistent with those described above, only the coefficients on real GDP growth are somewhat larger, now capturing the entire business cycle. This can be seen as a first robustness check of our results.

\footnotetext{
${ }^{14}$ Let us add, however, that Browne and Kim (1993) and Feyen et al. (2011) consider social contributions also to have a positive effect, because they often provide protection against disability and old age, and the provision of these benefits could produce a positive income effect on personal insurance decisions.
} 


\section{Note on results for Solvency II dummy}

We find a negative sign for SOLVENCYII in the case of life insurance and positive in the case of non-life insurance, mostly significant. This confirms the importance of including the dummy in the models. We interpret the signs using two arguments. First, the adoption of the Solvency II regime caused a certain reclassification of insurance lines of business, and thus original premium dynamics originally observed in life insurance could be transferred to non-life insurance or vice versa. Second, the Solvency II regime coincides with the period of exceptionally low yields and thus a drop in the attractiveness of certain life insurance products. Therefore, part of the longer-term trends in insurance could be also captured by the SOLVENCYII parameter. The latter argument is supported by the fact that SOLVENCYII becomes less significant after including interest rate in the model (see the Effect of interest rates and endogeneity problem section and Table 8), however without changing the other results significantly. Given the SOLVENCYII dummy serves as a control variable, we do not evaluate the resulting parameter estimates, their signs and magnitude to a greater extent, claiming that it correctly controls for a part of the variance in premiums that should not be attributed to other variables.

\section{Robustness checks}

In this section, we demonstrate that our baseline results as reported in Table 2 are robust. First, we offer a very simple extension of our analysis with the effect of interest rates and also verify a possible problem with the endogeneity of the GDP_GROWTH variable. Interest rates have been part of the main models in some of the previous studies (mixed estimates), and our short robustness check shows why we do not include them. Then, we also account for a possible problem with the endogeneity of GDP_GROWTH and use a generalised method of moments (GMMs) estimator and instrumental variables (IVs) to relax the concerns. Second, we enrich our sample period by going back to 1983 . By doing so, we nearly double the number of observations in our baseline model of life and non-life insurance premiums. However, this comes at a price, as not all of our control variables are available during the 1983-1996 period. In this exercise, we exclude the savings rate (SAVINGS), the concentration ratio (CONCENT), and the change in the harmonised consumer price index of insurance products INSHICP. As such, this robustness check is mainly used to verify the point estimates regarding the impact of real GDP growth. Third, we split our sample into two subsamples by differentiating between more developed and less developed (post-communist) countries. This serves as a natural check of the sample homogeneity. In addition, it allows us to check whether our reported estimates were affected by different speeds of adjustment in the convergence process across countries. This may be a concern for the variables FDI and CONCENT. Fourth, we dig deeper into the non-life insurance sector and regress each of its subsectors separately while keeping the list of controls unchanged. This caters to the fact that the non-life insurance sector is rather heterogeneous on its own, offering a wide range of services. 


\section{Effect of interest rates and endogeneity problem}

Table 8 describes our first two robustness checks. The first one adds a variable to the regression that controls the effect of long-term interest rates (rates on 10-year government bonds). In both regressions (1) and (3), this variable is not significant and thus partially confirms the results of previous studies, which offered mixed results. However, other regression coefficients do not deviate much from the baseline in Table 2 by adding this variable and hence seem robust. Let us add that this particular analysis employs only 23 countries, as data on 10-year government bonds are not available for Estonia.

To check for possible endogeneity of the variable representing GDP_GROWTH, we use a Blundell and Bond (1998) estimator (or system GMM estimator), employing GMM with IVs. We instrument the variable by its own lags, which can somewhat alleviate the endogeneity problem. In order to alleviate some known problems with the GMM approach, we use a corrected one-step GMM estimator with standard errors that are robust to heteroscedasticity and arbitrary patterns of autocorrelation within individuals. To mitigate the problem of too many instruments, we use only a subset of the available instrument matrix. In particular, 'GMM type' instruments are still generated for each period, but we collapse the instrument set according to Roodman (2009). Regressions in columns (2) and (4) employing the abovementioned approach show that our estimates have not changed much. The essential variables remain significant and have the expected sign. The variable GDP growth, which may suffer from the mentioned endogeneity, also retains its significance and sign.

We include this empirical exercise only as a robustness test for several reasons. First, the reverse relationship between GDP growth and insurance premiums is likely to be statistically weak, given that insurance accounts for a relatively small part of GDP. ${ }^{15}$ Second, the relationship is expected to be of longer-term nature and concerns mostly life insurance. As stated by Lee et al. (2013), there is a long-run equilibrium relationship between real GDP and life insurance premiums. Similarly, Kugler et al. (2005) shows that there is a long run relationship between insurance market size and economic growth rather than a through-the-cycle relationship. Third, while sophisticated GMM estimators are indispensable for complicated estimation problems (Wooldridge 2001), they can suffer from finite-sample problems and are much less straightforward then a simple OLS regression.

\section{Enlarged sample}

Table 3 replicates the baseline set of results in Table 2 . We confirm the historically important role of real GDP growth in explaining the evolution of both life and non-life insurance premiums. If anything, the point estimates for the longer sample are more pronounced. Averaging across the estimates in columns (1) and (2) gives us an impact of a

\footnotetext{
15 The median insurance penetration (insurance written to GDP) for life insurance in our sample is only $2.49 \%$.
} 
Table 3 Determinants of life and non-life premiums, 1983-2017

\begin{tabular}{|c|c|c|c|}
\hline & \multicolumn{3}{|l|}{ Dependent variable } \\
\hline & \multicolumn{2}{|l|}{ LIFEPREMIUMS } & \multirow{2}{*}{$\begin{array}{l}\text { NONLIFEPREMIUMS } \\
\text { (3) }\end{array}$} \\
\hline & (1) & (2) & \\
\hline \multirow[t]{2}{*}{$\overline{\text { GDP_GROWTH }}$} & $1.838 * * *$ & $1.384 * * *$ & $0.660 * *$ \\
\hline & $(0.379)$ & $(0.279)$ & $(0.267)$ \\
\hline \multirow[t]{2}{*}{ SOLVENCYII } & $-14.083^{* * *}$ & $-5.683 * *$ & 0.257 \\
\hline & $(3.147)$ & $(2.279)$ & $(1.883)$ \\
\hline \multirow[t]{2}{*}{ SSCGOVREV } & 0.038 & -0.200 & -0.247 \\
\hline & $(0.674)$ & $(0.533)$ & $(0.328)$ \\
\hline \multirow[t]{2}{*}{ FDI } & $1.433 * * *$ & $1.131 * * *$ & -0.085 \\
\hline & $(0.462)$ & $(0.428)$ & $(0.203)$ \\
\hline \multirow[t]{2}{*}{ LIFEEXP } & & $-2.939 * * *$ & \\
\hline & & $(0.586)$ & \\
\hline \multirow[t]{2}{*}{ ADR } & 0.582 & 0.759 & \\
\hline & $(0.545)$ & $(0.575)$ & \\
\hline \multirow[t]{2}{*}{ EXPORT } & & & $-0.077^{*}$ \\
\hline & & & $(0.041)$ \\
\hline \multirow[t]{2}{*}{ CRISIS } & -8.480 & -3.735 & $-6.734 * * *$ \\
\hline & $(3.357)$ & $(3.573)$ & $(1.862)$ \\
\hline Observations & 597 & 597 & 594 \\
\hline $\mathrm{N}$ (countries) & 24 & 24 & 24 \\
\hline $\mathrm{R}^{2}$ & 0.145 & 0.215 & 0.065 \\
\hline Adjusted $\mathrm{R}^{2}$ & 0.102 & 0.174 & 0.017 \\
\hline F Statistic & $16.061 * * *(\mathrm{df}=6 ; 567)$ & $\begin{array}{l}22.188 * * *(\mathrm{df}= \\
\quad 7 ; 566)\end{array}$ & $6.508 * * *(\mathrm{df}=6 ; 564)$ \\
\hline
\end{tabular}

Cluster-robust standard errors are in parentheses

Statistical significance at the $1 \%, 5 \%$, and $10 \%$ level is indicated by $* * *, * *$, and $*$, respectively

one standard deviation increase in real GDP growth on life insurance premiums of about $5.1 \%$ at the $1 \%$ level of significance. Column (3) shows an impact on non-life premium growth of $2.1 \%$ at the $5 \%$ significance level. In these regressions, however, some of the controls are missing, so real GDP growth could have taken over part of their effects.

\section{Splitting the sample}

Having tested the importance of market concentration in the main text (see The role of market concentration section), we hypothesised that the effect of changes in the level of concentration in the non-life insurance market can vary substantially across countries with more and less developed insurance sectors. To check this hypothesis, we split our sample into developed and less developed (post-communist) countries. In the process, we can check whether there are any differences in the statistical significance of other determinants as well. 
Table 4 Determinants of life and non-life premiums in developed and less developed (Postcom) countries, 1997-2017

\begin{tabular}{|c|c|c|c|}
\hline Dependent $v$ & & & \\
\hline POSTCOM & & DEVELOPED & \\
\hline LIFE PR. & NONLIFE PR. & LIFE PR. & NONLIFE PR \\
\hline
\end{tabular}

(1)

(2)

(3)

(4)

\begin{tabular}{|c|c|c|c|c|}
\hline GDP_GROWTH & $\begin{array}{l}0.346 \\
(0.571)\end{array}$ & $\begin{array}{l}0.730^{* *} \\
(0.337)\end{array}$ & $\begin{array}{l}1.214 * * * \\
(0.286)\end{array}$ & $\begin{array}{l}0.528^{*} \\
(0.299)\end{array}$ \\
\hline SOLVENCYII & $\begin{array}{l}-9.540^{*} \\
(5.318)\end{array}$ & $\begin{array}{l}1.483 \\
(2.028)\end{array}$ & $\begin{array}{l}-6.928^{*} \\
(3.695)\end{array}$ & $\begin{array}{l}2.710 \\
(2.396)\end{array}$ \\
\hline SSCGOVREV & $\begin{array}{l}-3.081^{* * *} \\
(1.120)\end{array}$ & $\begin{array}{l}0.177 \\
(0.491)\end{array}$ & $\begin{array}{l}-1.371^{* *} \\
(0.632)\end{array}$ & $\begin{array}{l}-0.251 \\
(0.618)\end{array}$ \\
\hline INSHICP & $\begin{array}{l}-0.010 \\
(0.201)\end{array}$ & $\begin{array}{l}0.618 * * * \\
(0.100)\end{array}$ & $\begin{array}{l}-0.157 \\
(0.325)\end{array}$ & $\begin{array}{l}0.951 * * * \\
(0.193)\end{array}$ \\
\hline SAVINGS & $\begin{array}{l}2.191 * * * \\
(0.626)\end{array}$ & & $\begin{array}{l}0.716^{* *} \\
(0.362)\end{array}$ & \\
\hline FDI & $\begin{array}{l}1.951 * * * \\
(0.688)\end{array}$ & $\begin{array}{l}0.589^{*} \\
(0.346)\end{array}$ & $\begin{array}{l}1.267 * * * \\
(0.474)\end{array}$ & $\begin{array}{l}-0.480 \\
(0.310)\end{array}$ \\
\hline LCONCENT & $\begin{array}{l}0.106 \\
(0.530)\end{array}$ & & $\begin{array}{l}1.125 * * * \\
(0.331)\end{array}$ & \\
\hline EXPORT & & $\begin{array}{l}-0.185^{* *} \\
(0.090)\end{array}$ & & $\begin{array}{l}-0.114 * \\
(0.062)\end{array}$ \\
\hline NCONCENT & & $\begin{array}{l}-0.688^{* *} \\
(0.305)\end{array}$ & & $\begin{array}{l}0.054 \\
(0.193)\end{array}$ \\
\hline $\mathrm{ADR}$ & $\begin{array}{l}-0.743 \\
(0.748)\end{array}$ & & $\begin{array}{l}-0.071 \\
(1.039)\end{array}$ & \\
\hline CRISIS & $\begin{array}{l}-14.745^{* * *} \\
(5.291)\end{array}$ & $\begin{array}{l}0.330 \\
(2.397)\end{array}$ & $\begin{array}{l}-6.713^{*} \\
(3.954)\end{array}$ & $\begin{array}{l}-6.133^{* * * *} \\
(1.199)\end{array}$ \\
\hline Observations & 96 & 96 & 258 & 247 \\
\hline $\mathrm{N}$ (countries) & 8 & 8 & 16 & 16 \\
\hline $\mathrm{R}^{2}$ & 0.358 & 0.478 & 0.184 & 0.116 \\
\hline Adjusted $\mathrm{R}^{2}$ & 0.228 & 0.381 & 0.101 & 0.025 \\
\hline F Statistic & $\begin{array}{l}4.903 * * * \\
(\mathrm{df}=9 ; 79)\end{array}$ & $\begin{array}{l}9.172 * * * \\
(\mathrm{df}=8 ; 80)\end{array}$ & $\begin{array}{l}5.860^{* * *} \\
(\mathrm{df}=9 ; 233)\end{array}$ & $\begin{array}{l}3.654 * * * \\
(\mathrm{df}=8 ; 223)\end{array}$ \\
\hline
\end{tabular}

Cluster-robust standard errors are in parentheses

Statistical significance at the $1 \%, 5 \%$, and $10 \%$ level is indicated by $* * *, * *$, and $*$, respectively

The post-communist countries-namely, the Czech Republic, Estonia, Hungary, Latvia, Lithuania, Poland, Slovakia, and Slovenia—are generally characterised by lower social and economic development and less developed insurance sectors than 
Table 5 Concentration ratios in developed and less developed (Postcom) countries

\begin{tabular}{lllccc}
\hline & & $\mathrm{n}$ & Mean & Med. & $\begin{array}{c}\text { Med. change } \\
(2000-2017)\end{array}$ \\
\hline LIFE & POSTCOM & 155 & 75.28 & 75.35 & -26.18 \\
& DEVELOPED & 307 & 55.23 & 51.27 & 3,55 \\
\multirow{2}{*}{ NON-LIFE } & POSTCOM & 157 & 74.71 & 74.94 & -10.04 \\
& DEVELOPED & 298 & 49.57 & 48.83 & 17.43 \\
\hline
\end{tabular}

The analysed period is from 2000 to 2017 , because some data on concentration for post-communist countries is missing from 1997 to 2000

the other countries in our sample (Pye 2005; Wagstaff and Moreno-Serra 2009). ${ }^{16}$ The differences between the two groups of countries are clearly visible from Fig. 7, which plots the average penetration rate for developed and post-communist countries. Table 4 shows the regression results for the split sample.

Dividing the sample yields several differences compared to our baseline results as they appear in Table 2. For post-communist countries, the market concentration of the non-life sector (NCONCENT) enters significantly and negatively at the 5\% level of significance (Table 4, column 2). This is in contrast to the insignificant estimates reported for the whole sample (Table 2) and for the more developed countries subsample (Table 4, column 4). It is also contradictory to the results of the life sector in the whole sample. This paradox can be answered in two ways. It stems from either the differences between the life and non-life sectors or the differences between developed and post-communist countries.

Regarding the differences between the life and non-life sectors, it is possible that the quantity channel (the number of contracts) is more dominant in the non-life sector than in the life sector. In the case of the life sector, we argued that higher market concentration probably enhances the price channel of insurance premium growth, putting additional upward pressure on insurance premiums (as volumes). Higher prices, however, can reduce the number of new contracts as demand for products decreases. This is probably the case of the non-life sector, as the price channel is fully controlled by the variable INSHICP in this specification.

As for the differences between developed and post-communist countries, Table 5 presents the descriptive statistics of the concentration ratios in the two subsamples. It is apparent that the concentration of the insurance market (both life and non-life) is much higher in the post-communist countries, a fact which can be explained by somewhat impeded development of the insurance sector. The fact that concentration decreased significantly over the 2000-2017 period may also explain the negative sign on the concentration ratio in the non-life sector in Table 4 and the insignificant result for the life sector (which contrasts with the statistically significant and positive sign in the developed countries). As pointed out in Fenn et al. (2008), after a certain optimal point a concentrated

\footnotetext{
${ }^{16}$ We use the terms 'post-communist' and 'less developed' as synonyms, meaning that the post-communist countries have less developed insurance sectors but not necessarily lower levels of GDP per capita than the 'developed' countries.
} 


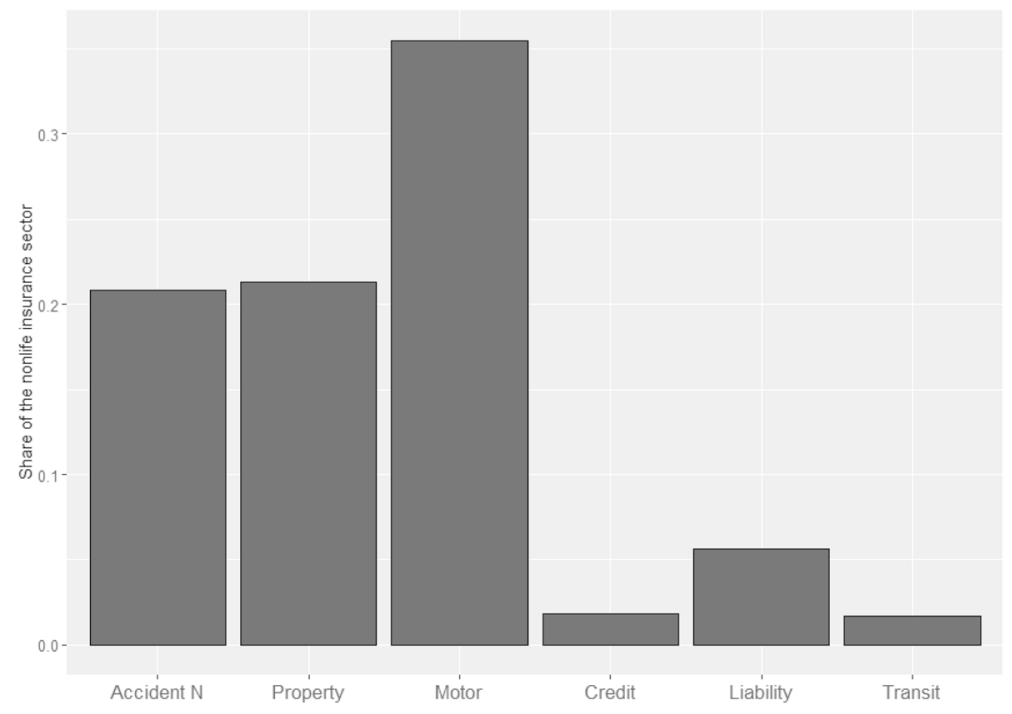

Fig. 5 Shares of subcategories of insurance in the non-life sector (2016). Source AXCO Database

market structure impedes the development of the non-life sector, and higher concentration ratios could then be associated with lower premium growth rates and lower concentration ratios with higher premium growth rates. The development of the non-life sector (growth of insurance premiums) in post-communist countries was probably driven largely by the process of deconcentration of this highly concentrated segment of the economy. This challenges the hypothesis of Outreville (1996), which we relied on above, that markets with few companies may be more successful in developing insurance services (i.e. higher insurance premium growth might be expected with a higher concentration ratio).

In the life insurance sector, too, the concentration ratio decreased over time in the post-communist countries. This would suggest an increasing quantity of premiums (a negative effect). However, the LCONCENT variable also partly reflects the price channel, which is not fully captured by the INSHICP variable in the life sector regression. The result is therefore not significant.

\section{Estimates for individual non-life subsectors}

Non-life insurance encompasses a broad range of services. It may cover people, property, or legal liabilities. Taken together, it may be just too heterogeneous to analyse, and one might ask whether in-sample heterogeneity affected some of the estimates reported in Table 2, columns (3) and (4). For this purpose, we re-estimate our baseline model specification as it appears in Eq. (1), regressing each of the non-life subsectors one at a time.

Figure 5 takes a closer look at the non-life sector in our sample. It reveals that non-life insurance is dominated by motor and property insurance, which jointly accounts for more than $55 \%$ of non-life insurance. Non-life accident insurance (Accident $\mathrm{N}$ ) also holds a substantial share. The large share of property and motor 
insurance in the non-life sector explains why the variable INSHICP is statistically significant in all our regressions for the non-life sector. Price growth in property and motor insurance clearly drives the positive and statistically significant growth in the volume of insurance premiums in the sector as a whole.

Table 10 in the Appendix shows the estimated coefficients and cluster-robust standard errors for the six non-life subsector regressions. Except for the transit category, all the regressions show that the growth of non-life premiums in particular subsectors is substantially influenced by the business cycle. The highest GDP_GROWTH parameter value can be observed in the motor, liability, and accident insurance segments. This may be intuitively well explained by the close linkage between households' and companies' income and/or wealth conditions and demand for the relevant insurance product. A drop in income implies lower demand for motor insurance due to either deferred car purchases or a shift to lower-priced insurance (through a reduction in the coverage or the additional features of the policy, for instance). Further, deferral of car purchases implies ageing cars and therefore also lower amounts insured. Occupation-related liability insurance is, in turn, linked to the existence of a profession that requires such insurance and therefore to general employment. Similarly, personal liability insurance may be cancelled by households, as it represents a luxury rather than a necessary good. Analogously, at least part of accident insurance also represents a luxury good linked to travelling and other leisure activities, which may be expected to be limited during an economic downturn. The results further suggest some procyclicality of credit insurance premiums, in line with the interrelated business and credit cycles.

In the case of property insurance, the GDP_GROWTH coefficient obtained can be intuitively explained by two opposing factors. First, the statistically significant positive linkage between premiums and real GDP growth-similarly to other segments that show such a linkage - may be interpreted as being closely related to household income and wealth, a drop in which may imply a reduction in the coverage or the additional features of property insurance policies. This is also related to the prevailing correlation between growth in real estate prices and the business cycle dynamics. The second opposing factor is the lower flexibility of this type of insurance, as such products are often connected with long-term mortgages, which makes them more stable over time. We see this as a possible explanation of why the estimated sensitivity to real GDP growth is less than 1 in the case of property insurance.

Finally, although transit insurance seems to be unrelated to real GDP growth according to the estimated parameter values, it is strongly affected by the CRISIS dummy instead. We interpret this as meaning that whereas minor business fluctuations do not change the demand for transit insurance, a major economic downturn (such as the GFC of 2008-2009) still has a severe impact on the segment.

Interestingly, our empirical model explains the property and motor categories better than others. The results are similar to the model of the non-life sector as a whole and are probably determined by the fact that these categories have the lowest level of cross-country heterogeneity in terms of market shares. Both of them involve insurance of 'tangible' products, which leads to general similarity. They are directly affected by price effects with low levels of nominal rigidity (see the coefficients 
on INSHICP for these segments in Table 10) and therefore best correspond to our model design.

On the other hand, the concentration ratio (LCONCENT), which turned out to be insignificant in the model for the non-life sector as a whole, is significant (and negative) primarily in the insurance of financial products grouped in the categories of credit (surety, bonds, and credit) and liability, as well as in transit insurance. We explain this as being a consequence of the smaller size of these segments (see Fig. 5) combined with a greater need for expert knowledge for the valuation of these insurance products. Growth of credit insurance premiums is also determined by financial development ( FDI), which also contrasts with the model for the non-life sector as a whole. We consider this an intuitive result, given that greater financial development and therefore also a larger amount of financial assets in the economy and more extensive use of financial products, including loans, increases the need for such insurance. The results above only confirm our prior belief that the non-life sector is quite heterogeneous and the regression for the sector as a whole can produce partially misleading results. The results should therefore be interpreted with caution.

Similarly to the aggregate results, we consider the significance of the SOLVENCYII parameter estimates to be mostly connected to product reclassification caused by adoption of the Solvency II regime. This could be particularly the issue for nonlife accident insurance as a consequence of unbundling of certain insurance contracts previously falling into the life insurance segment.

\section{Conclusion}

In this paper, we provide evidence on the importance of various macrofinancial determinants of insurance premium growth. We compile a rich dataset of insurance premiums for both the life and non-life insurance businesses for 24 European countries spanning the 1997-2017 period. We select the potential determinants of insurance premium growth based on a literature survey. In addition, we test for the significance of several variables that have not previously been tested or for which conclusive evidence has been missing. We conduct numerous robustness checks to verify our estimates.

Our panel estimation confirms that insurance sector premiums, both life and nonlife, co-move closely with the business cycle owing to its strong positive and statistically significant relationship with real GDP growth. Moreover, we offer other findings that advance the current knowledge on the topic.

First, we show that a more concentrated insurance market records a higher premium volume in various specifications for the life insurance sector. This is due either to higher price growth in the more concentrated sector or to the fact that a market with few companies can paradoxically be more successful in rapidly developing the sector, or both. In some segments of non-life insurance, and in post-communist countries, we record a negative impact of higher concentration on insurance premium growth. In the case of post-communist countries, this estimate is driven by the fact that the sector was 
initially highly concentrated, probably to the extent that this concentration was detrimental to the development of the sector as a whole. As our analysis shows, there has been considerable deconcentration in these countries over the last 20 years, which may have led to faster development of the sector as a whole. Given that we fully control for price growth in the non-life sector, the quantity effect of the concentration ratio on non-life premiums is supposed to be negative, as our results suggest.

To our knowledge, we are the first to use micro-level data on individual insurance companies to compute the concentration ratio that we use in our set of regressions. Our estimate can thus be considered a refinement of those other studies which rely on dummy variables to identify a more or less concentrated sector (Outreville 1996; Feyen et al. 2011). Our analysis encourages further research to determine what level of concentration contributes to faster development of the sector as a whole and what level of concentration is already harmful. Some form of threshold model would be worth considering here.

Second, we discover a significant role of price effects. Since premiums are a joint outcome of volume and price, we include changes in insurance prices in our regression. Given our sample focus on European countries, we can regress insurance premiums on changes in insurance prices as measured by the HICPs. Previous studies rely on general inflation, which captures monetary policy uncertainty rather than price effects. In this respect, we believe our procedure allows us to filter out a significant portion of the statistical noise from the estimation by controlling for changes in insurance prices. Therefore, we may record generally more precise parameters compared to the previous line of work. We find that a change in price is related to a significant increase in the volume of premiums in the same direction for the non-life sector, whereas the volume of life premiums records no change or moves oppositely. Knowing this, we explain the inconsistent results of previous studies, noting that on the one hand the general inflation variable largely captures prices of real goods such as cars and real estate. Growth in the prices of those goods then naturally raises the prices of non-life insurance premiums. The fact that the volume increases in line with the growth in prices also highlights that the demand for non-life insurance is rather inelastic, given that no close substitutes exist for a range of non-life insurance products. On the other hand, life insurance demand is highly sensitive to the changes in prices, which causes the change in premium volume to be insignificant or even in the opposite direction than the change in prices.

Third, we show that the inclusion of the life expectancy variable in the model of life insurance premiums can be a source of noise and may have been misinterpreted in some of the previous studies. In this respect, we show that life expectancy captures convergence effects rather than improvements in the healthcare system or in the general health of the population.

Our estimated parameters can be used to refine the existing macroprudential stress tests of the insurance sector. The estimated linkages between the set of determinants of insurance premium growth may serve both for backward-looking evaluation of the development of the insurance sector and for derivation of forward-looking insurancespecific scenarios from the macroeconomic scenarios used in stress testing. 
The relevance of our results and the importance of the resilience of the insurance sector are highlighted by the current COVID-19 pandemic. In connection with the pandemic, insurers can expect an increase in claims in life insurance and in certain non-life insurance sectors (credit, income, worker, and business interruption insurance), though possibly mitigated by exclusion clauses for diseases and pandemics. Our results - the proven positive link between real GDP growth and insurance premiums-imply that the insurance business may also be hit by a drop in insurance premiums during the pandemic. Given the possible longer-term negative impact of the pandemic on economic performance, our finding is important, as it signals that the temporary one-off increase in claims may not be the most important channel through which the pandemic affects insurance companies.

Finally, our findings may be relevant for both insurance companies and supervisory authorities when foreseeing future developments in the insurance industry. Given the identified linkage between economic and insurance cyclicality, insurance companies may consider careful evaluation of present economic conditions and prospects of their future changes as a sound starting point when considering strategic focus on certain insurance products, using the presented parameter estimates as a simple way of translating available macroeconomic projections to predictions of growth in various lines of business. Similarly, the estimate of the GDP-premiums nexus can be utilised by supervisory authorities assessing the resilience of supervised insurance companies to an expected or hypothetical deterioration in GDP growth. Further, the ongoing discussion regarding the possible extension of the European insurance regulatory framework by certain macroprudential elements can benefit from the findings. On one hand, our results imply that it might be reasonable to partially link potential counter-cyclical policy tools to economic conditions. On the other hand, and simultaneously, the significant heterogeneity in insurance, which was also documented by our findings, needs to be taken into account when designing such tools.

\section{A Robustness checks, data and charts}

See Figs. 6 and 7 and Tables 6, 7, 8, 9 and 10. 

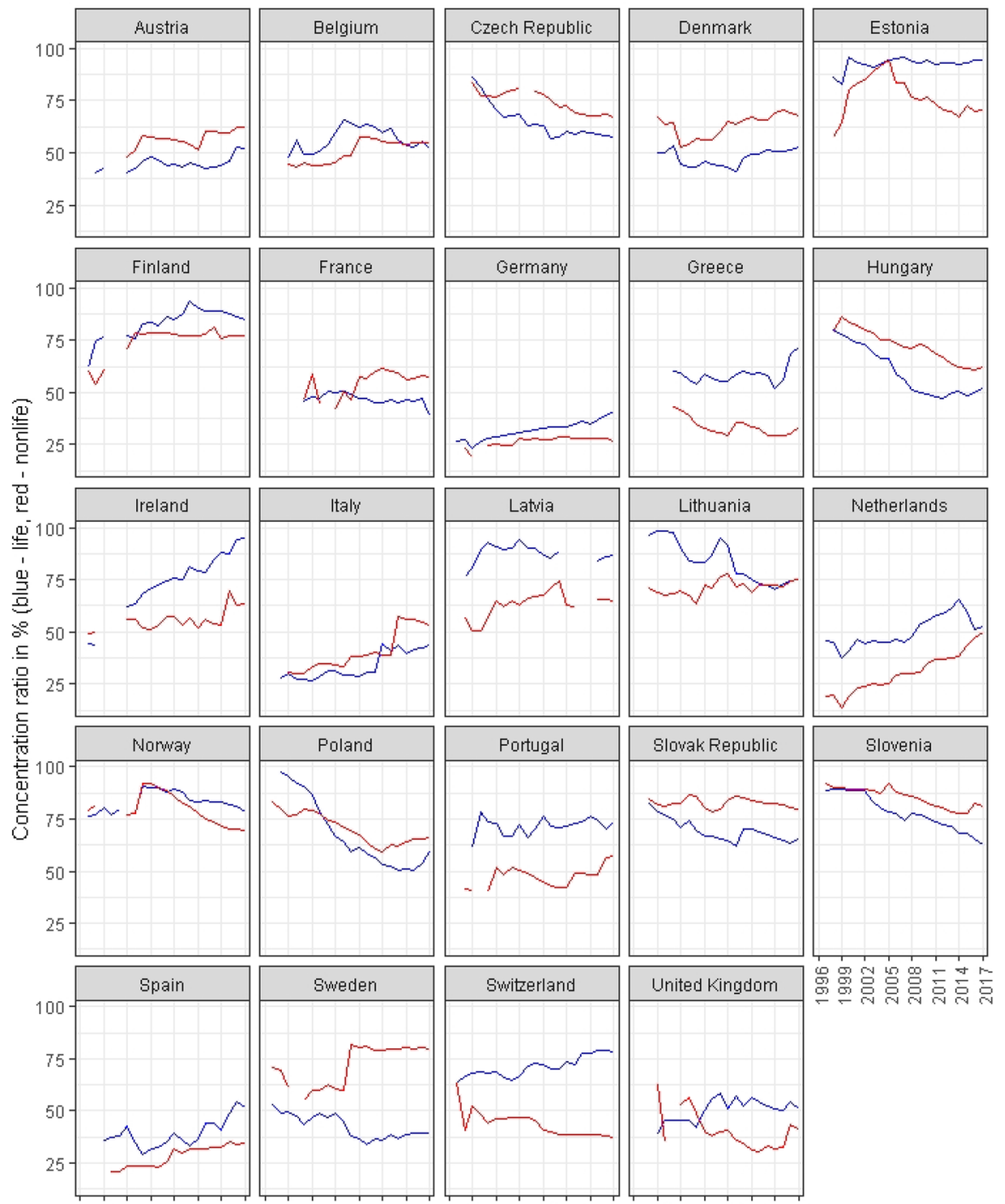

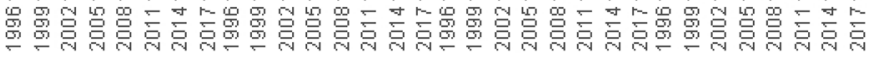

Year

Fig. 6 Concentration ratios, life and non-life sectors (1997-2017). Note concentration ratios are based on company-level data and calculated as the market share of the four largest insurance companies providing life/non-life insurance in the given year and country. Source AXCO Database 
6

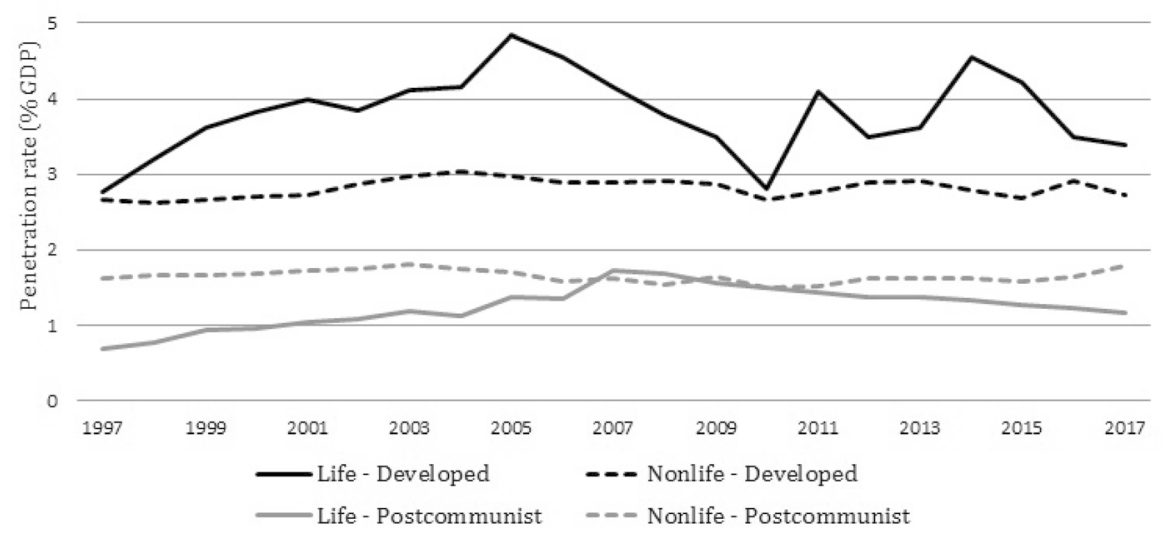

Fig. 7 Penetration rates in developed and post-communist countries (1997-2017). Source AXCO Database and OECD Insurance Statistics Database 


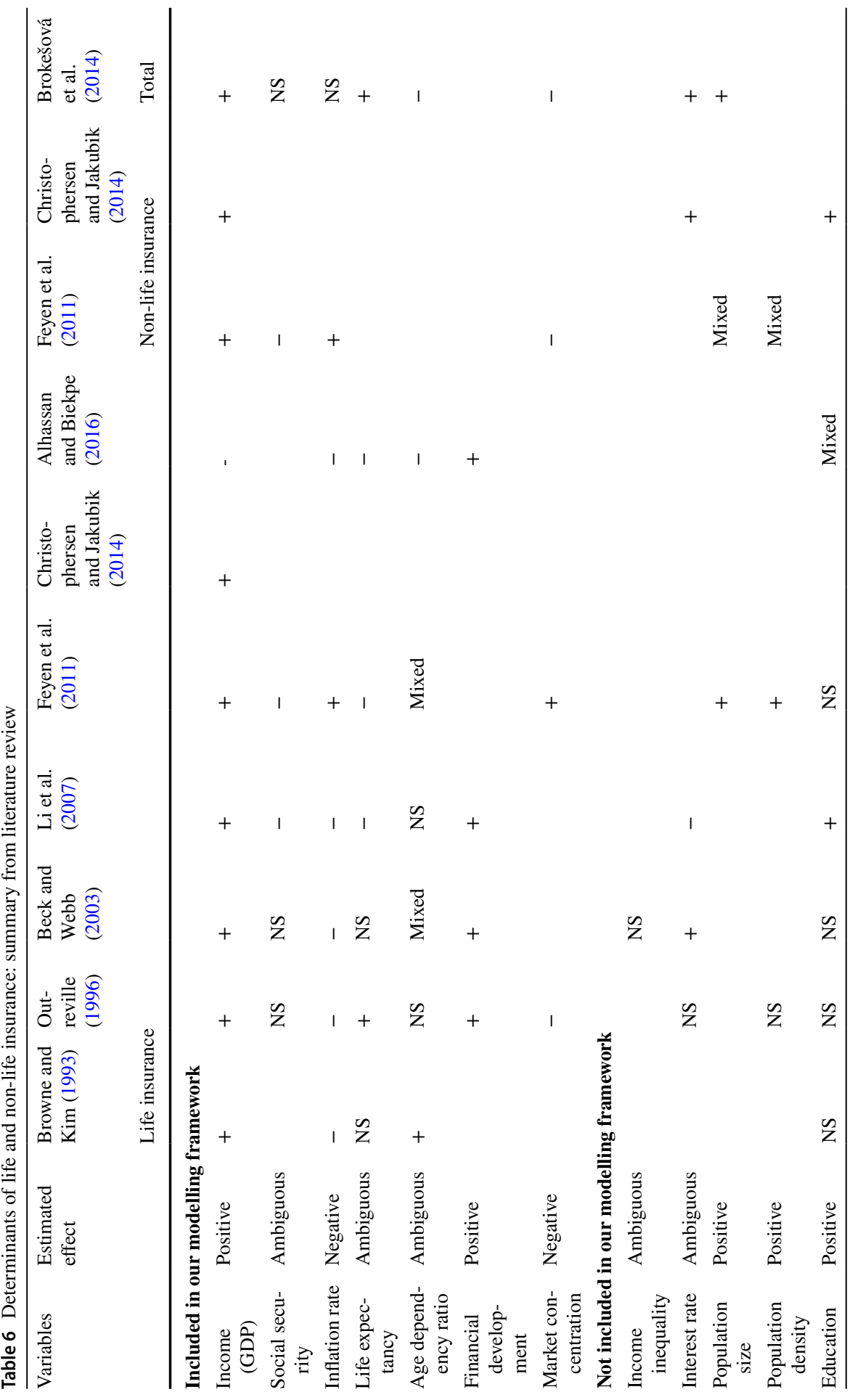

就 


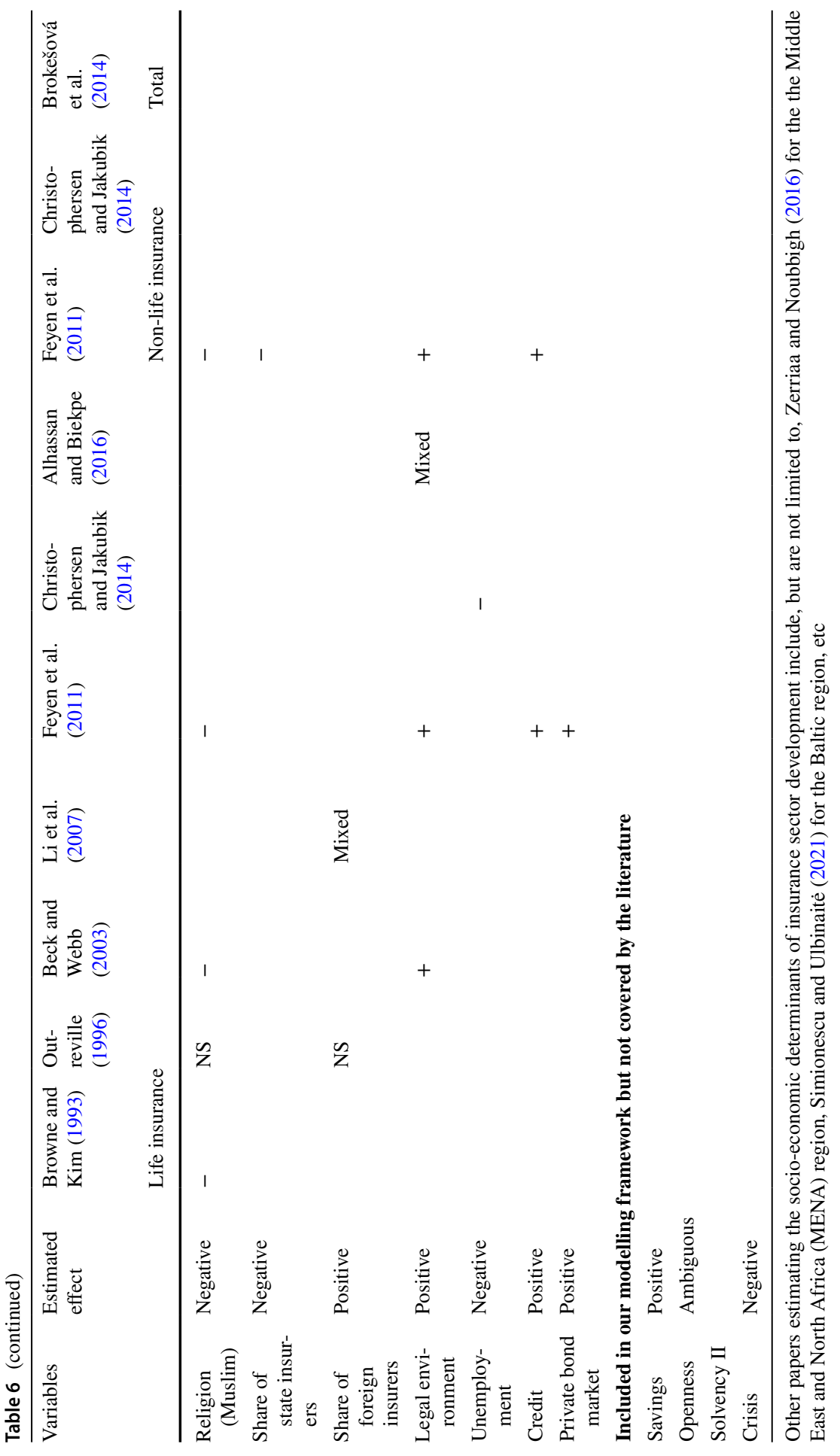




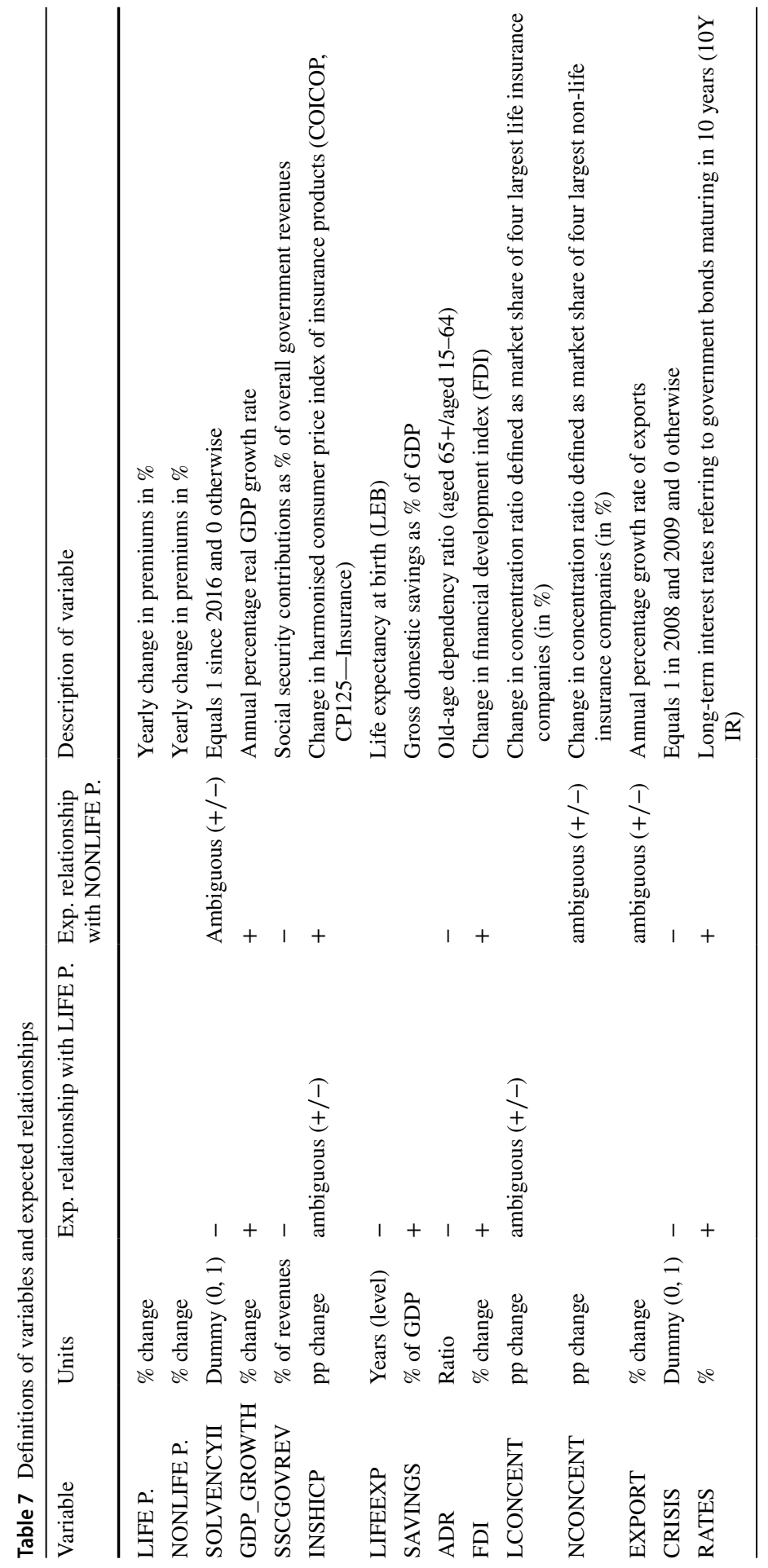

承 
Table 8 Determinants of life and non-life premiums, 1997-2017, RATES included, ENDOGENEITY CHECK

\begin{tabular}{|c|c|c|c|c|}
\hline & \multicolumn{4}{|c|}{ Dependent variable } \\
\hline & \multicolumn{2}{|c|}{ LIFEPREMIUMS } & \multicolumn{2}{|c|}{ NONLIFEPREMIUMS } \\
\hline & (1) & (2) & (3) & (4) \\
\hline & + RATES & GMM (IV) & + RATES & GMM (IV) \\
\hline \multirow[t]{2}{*}{ GDP_GROWTH } & $1.241^{* * *}$ & $1.018 * * *$ & $0.574 * *$ & $0.531^{* *}$ \\
\hline & $(0.258)$ & $(0.269)$ & $(0.713)$ & $(0.262)$ \\
\hline \multirow[t]{2}{*}{ SOLVENCYII } & $-6.732 *$ & -7.725 & $3.262 * * *$ & 2.910 \\
\hline & $(3.549)$ & $(3.805)$ & $(2.955)$ & (1.785) \\
\hline \multirow[t]{2}{*}{ SSCGOVREV } & $-1.659 * * *$ & $-2.182^{* * *}$ & -0.201 & -0.198 \\
\hline & $(0.629)$ & $(1.092)$ & $(0.788)$ & $(0.490)$ \\
\hline \multirow[t]{2}{*}{ INSHICP } & -0.129 & -0.005 & $0.639 * * *$ & $0.775^{* * *}$ \\
\hline & $(0.171)$ & $(0.191)$ & $(0.179)$ & $(0.093)$ \\
\hline \multirow[t]{2}{*}{ SAVINGS } & $0.977 * * *$ & $1.255^{* * *}$ & & \\
\hline & $(0.299)$ & $(0.427)$ & & \\
\hline \multirow[t]{2}{*}{ FDI } & $1.415 * * *$ & $1.413 * * *$ & -0.378 & -0.405 \\
\hline & $(0.456)$ & $(0.446)$ & $(0.293)$ & $(0.325)$ \\
\hline \multirow[t]{2}{*}{ LCONCENT } & $0.876^{* * *}$ & $0.865 * * *$ & & \\
\hline & $(0.299)$ & $(0.316)$ & & \\
\hline \multirow[t]{2}{*}{$\mathrm{ADR}$} & 0.011 & -0.006 & & \\
\hline & $(0.666)$ & (1.119) & & \\
\hline \multirow[t]{2}{*}{ NCONCENT } & & & -0.005 & 0.011 \\
\hline & & & $(0.185)$ & $(0.220)$ \\
\hline \multirow[t]{2}{*}{ EXPORT } & & & $-0.103^{* *}$ & $-0.139 * * *$ \\
\hline & & & $(0.053)$ & $(0.053)$ \\
\hline \multirow[t]{2}{*}{ CRISIS } & $-7.651^{* *}$ & $-8.178^{* *}$ & $-3.459 * *$ & $-4.004^{* *}$ \\
\hline & $(3.383)$ & $(3.802)$ & $(3.477)$ & $(1.775)$ \\
\hline \multirow[t]{2}{*}{ RATES } & 0.716 & & 0.299 & \\
\hline & $(0.556)$ & & $(0.196)$ & \\
\hline Observations & 346 & 320 & 343 & 304 \\
\hline $\mathrm{N}$ (countries) & 23 & 24 & 23 & 24 \\
\hline $\mathrm{R}^{2}$ & 0.196 & & 0.149 & \\
\hline Adjusted $\mathrm{R}^{2}$ & 0.114 & & 0.062 & \\
\hline F statistic & $\begin{array}{c}16.510^{* * * *}(\mathrm{df}= \\
10 ; 321)\end{array}$ & & $\begin{array}{l}25.180 * * *(\mathrm{df}= \\
9 ; 311)\end{array}$ & \\
\hline Sargan (Hansen) test & & $24[0.844]$ & & $24[0.844]$ \\
\hline Arellano-Bond test & & $-0.65[0.518]$ & & $-0.43[0.669]$ \\
\hline
\end{tabular}

Cluster-robust standard errors are in parentheses

Statistical significance at the $1 \%, 5 \%$, and $10 \%$ level is indicated by ***, **, and *, respectively. We test the validity of the instrumental variables in two ways. First, we examine the second order serial correlation of differenced residuals (AR2), as proposed by Arellano and Bond (1991). Second, we test the validity of all orthogonality conditions for the overidentified model by the Hansen (1982) test. This overidentification test is theoretically superior for a robust one-step estimator and it is based on the Hansen statistic from a two-step estimate 
Table 9 Determinants of life and non-life premiums, 1997-2017, CRISIS dummy not included

\begin{tabular}{|c|c|c|c|c|}
\hline & \multicolumn{4}{|l|}{ Dependent variable } \\
\hline & \multicolumn{2}{|l|}{ LIFEPREMIUMS } & \multicolumn{2}{|c|}{ NONLIFEPREMIUMS } \\
\hline & (1) & (2) & (3) & (4) \\
\hline GDP_GROWTH & $\begin{array}{l}1.345^{* * *} \\
(0.318)\end{array}$ & $\begin{array}{l}1.056^{* * * *} \\
(0.313)\end{array}$ & $\begin{array}{l}0.695 * * * \\
(0.229)\end{array}$ & $\begin{array}{l}0.585 * * * \\
(0.217)\end{array}$ \\
\hline SOLVENCYII & $\begin{array}{l}-8.946^{* * * *} \\
(3.228)\end{array}$ & $\begin{array}{l}-5.528^{*} \\
(2.887)\end{array}$ & $\begin{array}{l}2.519 \\
(1.752)\end{array}$ & $\begin{array}{l}4.996 * * \\
(2.068)\end{array}$ \\
\hline SSCGOVREV & $\begin{array}{l}-1.933^{* * * *} \\
(0.610)\end{array}$ & $\begin{array}{l}-1.579 * * \\
(0.649)\end{array}$ & $\begin{array}{l}-0.378 \\
(0.549)\end{array}$ & $\begin{array}{l}-0.252 \\
(0.482)\end{array}$ \\
\hline INSHICP & $\begin{array}{l}-0.045 \\
(0.177)\end{array}$ & $\begin{array}{l}-0.272 * * \\
(0.132)\end{array}$ & $\begin{array}{l}0.696 * * * \\
(0.075)\end{array}$ & $\begin{array}{l}0.604 * * * \\
(0.069)\end{array}$ \\
\hline SAVINGS & $\begin{array}{l}0.873 * * * \\
(0.287)\end{array}$ & $\begin{array}{l}0.721 * * \\
(0.324)\end{array}$ & & \\
\hline FDI & $\begin{array}{l}1.152^{* *} \\
(0.452)\end{array}$ & $\begin{array}{l}0.886^{*} \\
(0.460)\end{array}$ & $\begin{array}{l}-0.455 \\
(0.313)\end{array}$ & $\begin{array}{l}-0.529 \\
(0.347)\end{array}$ \\
\hline LCONCENT & $\begin{array}{l}0.845^{* * *} \\
(0.306)\end{array}$ & $\begin{array}{l}0.898^{* * *} \\
(0.294)\end{array}$ & & \\
\hline LIFEEXP & & $\begin{array}{l}-3.667^{* * *} \\
(0.827)\end{array}$ & & $\begin{array}{l}-1.457^{* * *} \\
(0.480)\end{array}$ \\
\hline $\mathrm{ADR}$ & $\begin{array}{l}0.189 \\
(0.699)\end{array}$ & $\begin{array}{l}0.952 \\
(0.651)\end{array}$ & & \\
\hline NCONCENT & & & $\begin{array}{l}-0.010 \\
(0.184)\end{array}$ & $\begin{array}{l}0.020 \\
(0.194)\end{array}$ \\
\hline EXPORT & & & $\begin{array}{l}-0.116 * * \\
(0.052)\end{array}$ & $\begin{array}{l}-0.121^{* *} \\
(0.055)\end{array}$ \\
\hline Observations & 354 & 354 & 343 & 343 \\
\hline $\mathrm{N}$ (countries) & 24 & 24 & 20 & 20 \\
\hline $\mathrm{R}^{2}$ & 0.178 & 0.215 & 0.131 & 0.147 \\
\hline Adjusted $\mathrm{R}^{2}$ & 0.099 & 0.137 & 0.048 & 0.063 \\
\hline F Statistic & $\begin{array}{l}8.702 * * *(\mathrm{df}=8 \\
322)\end{array}$ & $\begin{array}{l}9.784 * * *(\mathrm{df}=9 \\
321)\end{array}$ & $\begin{array}{l}6.739 * * * \\
\quad(\mathrm{df}=7 \\
312)\end{array}$ & $6.726^{* * *}(\mathrm{df}=8 ; 311)$ \\
\hline
\end{tabular}

Cluster-robust standard errors are in parentheses

Statistical significance at the $1 \%, 5 \%$, and $10 \%$ level is indicated by ***, **, and *, respectively 
Table 10 Non-life premiums subsectors, OECD countries 1997-2017

Dependent variable

Accident N Property Motor Credit Liability Transit

(2)

$\mathrm{GDP}_{\text {GROWTH }}$

\begin{tabular}{|c|c|c|c|c|c|c|}
\hline & $(0.569)$ & $(0.154)$ & $(0.187)$ & $(0.493)$ & $(0.253)$ & $(0.432)$ \\
\hline \multirow[t]{2}{*}{ SOLVENCYII } & $9.253 * *$ & $-2.788 * *$ & 1.875 & 0.002 & $-4.045^{* *}$ & 0.058 \\
\hline & $(4.389)$ & $(1.222)$ & (1.498) & (3.805) & (2.034) & $(3.461)$ \\
\hline \multirow[t]{2}{*}{ SSCGOVREV } & -1.157 & $-0.542 * *$ & $-0.679 * *$ & 0.646 & -0.016 & 0.434 \\
\hline & $(0.781)$ & $(0.217)$ & $(0.265)$ & $(0.671)$ & $(0.371)$ & $(0.613)$ \\
\hline \multirow[t]{2}{*}{ INSHICP } & 0.181 & $0.290 * * *$ & $0.670 * * *$ & -0.016 & 0.109 & 0.220 \\
\hline & $(0.258)$ & $(0.072)$ & $(0.088)$ & $(0.221)$ & $(0.118)$ & $(0.204)$ \\
\hline \multirow[t]{2}{*}{ FDI } & 0.287 & 0.186 & 0.203 & $0.624 *$ & -0.111 & -0.149 \\
\hline & $(0.445)$ & $(0.123)$ & $(0.150)$ & $(0.377)$ & $(0.218)$ & $(0.347)$ \\
\hline \multirow[t]{2}{*}{ NCONCENT } & -0.330 & 0.134 & 0.060 & $-0.884 * *$ & $-0.417 * *$ & $-0.823^{* * * *}$ \\
\hline & $(0.365)$ & $(0.100)$ & $(0.123)$ & $(0.370)$ & $(0.172)$ & $(0.283)$ \\
\hline \multirow[t]{2}{*}{ EXPORT } & -0.160 & $-0.166^{* * * *}$ & $-0.168 * *$ & 0.124 & $-0.227^{* *}$ & -0.080 \\
\hline & (0.192) & $(0.054)$ & $(0.065)$ & $(0.172)$ & $(0.089)$ & $(0.151)$ \\
\hline \multirow[t]{2}{*}{ CRISIS } & 0.661 & -0.651 & -0.511 & -3.470 & -2.479 & $-7.521^{* *}$ \\
\hline & (4.888) & (1.349) & $(1.651)$ & $(4.266)$ & $(2.256)$ & $(3.814)$ \\
\hline Observations & 398 & 397 & 399 & 352 & 373 & 399 \\
\hline $\mathrm{N}$ (countries) & 24 & 24 & 24 & 24 & 24 & 24 \\
\hline $\mathrm{R}^{2}$ & 0.050 & 0.206 & 0.322 & 0.050 & 0.149 & 0.055 \\
\hline Adjusted $\mathrm{R}^{2}$ & -0.030 & 0.138 & 0.265 & -0.042 & 0.072 & -0.025 \\
\hline \multirow[t]{2}{*}{ F statistic } & $2.417 * *$ & $11.833^{* * *}$ & $21.793 * * *$ & $2.088 * *$ & $7.483 * * *$ & $2.672 * * *$ \\
\hline & $(\mathrm{df}=8 ; 366)$ & $(\mathrm{df}=8 ; 365)$ & $(\mathrm{df}=8 ; 367)$ & $(\mathrm{df}=8 ; 320)$ & $(\mathrm{df}=8 ; 341)$ & $(\mathrm{df}=8 ; 367)$ \\
\hline
\end{tabular}

Cluster-robust standard errors are in parentheses

Statistical significance at the $1 \%, 5 \%$, and $10 \%$ level is indicated by $* * *, * *$, and *, respectively

Conflict of interest The authors declare that thay have no conflict of interest.

\section{References}

Acharya, V.V., and M. Richardson. 2014. Is the insurance industry systemically risky. In Modernizing insurance regulation, 151-180. https://doi.org/10.1002/9781118766798.ch9.

Alhassan, A.L., and N. Biekpe. 2016. Determinants of life insurance consumption in Africa. Research in International Business and Finance 37: 17-27.

Alves, I., J. Brinkhoff, S. Georgiev, J.-C. Héam, I. Moldovan, and C.M. Di Scotto. 2015. Network analysis of the EU insurance sector. ESRB occasional paper 7. European Systemic Risk Board.

Babbel, D.F. 1985. The price elasticity of demand for whole life insurance. The Journal of Finance 40 (1): 225-239.

Balcilar, M., R. Gupta, C.-C. Lee, and G. Olasehinde-Williams. 2018. The synergistic effect of insurance and banking sector activities on economic growth in Africa. Economic Systems 42 (4): 637-648.

Beck, T., and I. Webb. 2003. Economic, demographic, and institutional determinants of life insurance consumption across countries. The World Bank Economic Review 17 (1): 51-88. 
Bikker, J.A., and M. Van Leuvensteijn. 2008. Competition and efficiency in the Dutch life insurance industry. Applied Economics 40 (16): 2063-2084.

Brokešová, Z., E. Pastoráková, and T. Ondruška. 2014. Determinants of insurance industry development in transition economies: Empirical analysis of Visegrad group data. The Geneva Papers on Risk and Insurance-Issues and Practice 39 (3): 471-492.

Browne, M.J., and K. Kim. 1993. An international analysis of life insurance demand. Journal of Risk and Insurance 60 (4): 616-634.

Burnett, J.J., and B.A. Palmer. 1984. Examining life insurance ownership through demographic and psychographic characteristics. Journal of Risk and Insurance 51 (3): 453-467.

Christophersen, C., and P. Jakubik. 2014. Insurance and the macroeconomic environment. EIOPA-Financial Stability Report, 44-55.

Cummins, J.D., M. Rubio-Misas, and D. Vencappa. 2017. Competition, efficiency and soundness in European life insurance markets. Journal of Financial Stability 28: 66-78.

Fenn, P., D. Vencappa, S. Diacon, P. Klumpes, and C. O'Brien. 2008. Market structure and the efficiency of European insurance companies: A stochastic frontier analysis. Journal of Banking and Finance 32 (1): 86-100.

Feyen, E., R.R. Lester, and R.D.R. Rocha. 2011. What drives the development of the insurance sector? An empirical analysis based on a panel of developed and developing countries. Policy research working paper 5572. World Bank.

Gupta, R., A. Lahiani, C.-C. Lee, and C.-C. Lee. 2019. Asymmetric dynamics of insurance premium: The impacts of output and economic policy uncertainty. Empirical Economics 57 (6): 1959-1978.

Haiss, P., and K. Sümegi. 2008. The relationship between insurance and economic growth in Europe: A theoretical and empirical analysis. Empirica 35 (4): 405-431.

Hammond, J., D.B. Houston, and E.R. Melander. 1967. Determinants of household life insurance premium expenditures: An empirical investigation. Journal of Risk and Insurance 34 (3): 397-408.

Headen, R.S., and J.F. Lee. 1974. Life insurance demand and household portfolio behavior. Journal of Risk and Insurance 41 (4): 685-698.

Hodula, M., A. Melecky, and M. Machacek. 2020. Off the radar: Factors behind the growth of shadow banking in Europe. Economic Systems 44 (3): 100808.

IAIS. 2013. Macroprudential policy and surveillance in insurance. Macroprudential Surveillance and Policy Subcommittee (MPSSC), July 18. Basel: Bank for International Settlements. http://www. iaisweb.org/view/element_href.cfm?src=1/19149.pdf.

IAIS. 2020. Global insurance market report (GIMAR). Technical report. International Association of Insurance Supervisors: Bank for International Settlements.

Jiménez, G., S. Ongena, J.-L. Peydró, and J. Saurina Salas. 2017. Do demand or supply factors drive bank credit, in good and crisis times? 2012-003.

Jobst, M.A.A., N. Sugimoto, and T. Broszeit. 2014. Macroprudential solvency stress testing of the insurance sector. IMF working paper 14/133. International Monetary Fund.

Kugler, M., R. Ofoghi, et al. 2005. Does insurance promote economic growth? Evidence from the UK. In Money Macro and Finance (MMF) Research Group conference, vol 8. Citeseer.

Lee, C.-C., C.-C. Lee, and Y.-B. Chiu. 2013. The link between life insurance activities and economic growth: Some new evidence. Journal of International Money and Finance 32: 405-427.

Li, D., F. Moshirian, P. Nguyen, and T. Wee. 2007. The demand for life insurance in OECD countries. Journal of Risk and Insurance 74 (3): 637-652.

Lorent, B. 2008. Risks and regulation of insurance companies: Is solvency ii the right answer? CEB working papers 08-007. Université Libre de Bruxelles, Solvay Business School, Centre Emile Bernheim.

Nyholm, K. 2012. Insurance and banking interconnectedness in Europe: The opinion of equity markets. Economics Research International. https://doi.org/10.1155/2012/525089.

Outreville, J.F. 1996. Life insurance markets in developing countries. Journal of Risk and Insurance 63 (2): 263-278.

Peleckienė, V., K. Peleckis, G. Dudzevičiūtė, and K. Peleckis. 2019. The relationship between insurance and economic growth: Evidence from the European union countries. Economic ResearchEkonomska Istraživanja 32: 1138-1151.

Pye, R.B. 2005. The evolution of financial services in transition economies: An overview of the insurance sector. Post-Communist Economies 17 (2): 205-223.

Roodman, D. 2009. A note on the theme of too many instruments. Oxford Bulletin of Economics and Statistics 71 (1): 135-158. 
Sahay, R., M. Čihák, P. N’diaye, A. Barajas, R. Bi, D. Ayala, Y. Gao, A. Kyobe, L. Nguyen, and C. Saborowski. 2015. Rethinking financial deepening: Stability and growth in emerging markets. IMF staff discussion note 15/08. International Monetary Fund.

Simionescu, M., and A. Ulbinaitè. 2021. The relationship between insurance market and macroeconomic indicators in the Baltic states. Journal of Baltic Studies 52 (3): 1-24.

Smith, R.P. 2000. Estimation and inference with non-stationary panel time-series data. Technical report (mimeo).

Svirydzenka, K. 2016. Introducing a new broad-based index of financial development. IMF working paper 16/5. International Monetary Fund.

Wagstaff, A., and R. Moreno-Serra. 2009. Europe and Central Asia's great post-communist social health insurance experiment: Aggregate impacts on health sector outcomes. Journal of Health Economics 28 (2): 322-340.

Ward, D., and R. Zurbruegg. 2000. Does insurance promote economic growth? Evidence from OECD countries. Journal of Risk and Insurance 67 (4): 489-506.

Wooldridge, J.M. 2001. Applications of generalized method of moments estimation. Journal of Economic Perspectives 15 (4): 87-100.

Yaari, M.E. 1965. Uncertain lifetime, life insurance, and the theory of the consumer. The Review of Economic Studies 32 (2): 137-150.

Zerriaa, M., and H. Noubbigh. 2016. Determinants of life insurance demand in the MENA region. The Geneva Papers on Risk and Insurance-Issues and Practice 41 (3): 491-511.

Publisher's Note Springer Nature remains neutral with regard to jurisdictional claims in published maps and institutional affiliations.

\section{About the authors}

Martin Hodula received his PhD in Economics from the Faculty of Economics, VSB - Technical University of Ostrava. He has been working at the Czech National Bank since 2018, and since 2019 he has been the Head of Financial Research Coordination Unit in the Financial Stability Department and Deputy Director of the Financial Research Division. In his research, he focuses on the issues of financial stability (specifically, assessing the impact of macroprudential policy tools), banking sector regulation and nonbank financial intermediation.

Jan Janků received his Ph.D. in Economic Theory and M.Sc. in National Economy from the Faculty of Economics, Technical University of Ostrava (VSB-TUO). He has been working as an analyst in the Financial Stability Department of the Czech National Bank since 2019. In his research, he focuses on the issues of financial stability (specifically, assessing the impacts of macroprudential policy tools, the interaction of structural and cyclical systemic risks, and insurance sector determinants).

Martin Časta graduated from the Law Faculty at Charles University in Prague and also received a master's degree in Economic Analysis at the Faculty of Economics at the University of Economics. He is currently completing his doctorate at the Faculty of Finance and Accounting at the University of Economics. He has been working at the Czech National Bank, in the Macroprudential Analyses Division of the Financial Stability Department, since 2019. In his professional and research activities, his focus has been on selected issues in financial markets and financial stability.

Adam Kučera completed master's programs in Financial Engineering at the Faculty of Finance and Accounting of the University of Economics in Prague and Economic Theory at the Institute of Economic Studies of Charles University, where he is currently pursuing a doctoral program. He has been working at the Czech National Bank since 2015, and since October 2019 he has been the head of the financial markets department in the financial stability section. In his professional and research activities, he focuses on the issue of financial markets and especially on the issues of determinants of their development. 